This is an electronic reprint of the original article. This reprint may differ from the original in pagination and typographic detail.

Author(s): Junttila, Juha-Pekka; Korhonen, Marko

Title: $\quad$ Stock market information and the relationship between real exchange rate and real interest rates

Year: $\quad 2013$

Version:

Please cite the original version:

Junttila, J.-P., \& Korhonen, M. (2013). Stock market information and the relationship between real exchange rate and real interest rates. Applied Financial Economics, Vol 23(No 11), 901-920. https://doi.org/10.1080/09603107.2013.776662

All material supplied via JYX is protected by copyright and other intellectual property rights, and duplication or sale of all or part of any of the repository collections is not permitted, except that material may be duplicated by you for your research use or educational purposes in electronic or print form. You must obtain permission for any other use. Electronic or print copies may not be offered, whether for sale or otherwise to anyone who is not an authorised user. 


\title{
Stock Market Information and the Relationship Between Real Exchange Rate and Real Interest Rates *
}

\author{
Juha Junttila ${ }^{\dagger} \quad$ Marko Korhonen
}

February 11, 2013

\begin{abstract}
In this paper we propose to augment the traditional relationship between real exchange rates and real interest rates (RERI) by adding the stock market equilibrium condition to it. We introduce the relative dividend yield as the new information variable. In the empirical analysis we use recent monthly observations from the U.K., Japan, Canada and Eurozone, all relative to the U.S. We show that the introduction of stock market information is highly relevant for the functioning of the RERI hypothesis. Based on the results from the cointegration analysis the role of relative stock market performance is especially important in the shortterm (3 month) horizon, where the augmented RERI representation is most stronlgy supported.
\end{abstract}

Key words: real exchange rate, real interest rates, stock markets, cointegration

JEL classification: E44, F21, F31, F41

\section{Introduction}

The importance of real exchange rate in macroeconomic analyses is based on its role in reflecting the competitiveness of national real economies. One of the most intuitively and theoretically appealing approaches to model the behavior of the real exchange rate stems from the so called real exchange rate - real interest rate (RERI) parity. The original roots of this approach are in the sticky-price

*This study is part of the research program of the Oulu Macroeconomic Group (OMaG), and the financial support from the Yrjö Jahnsson foundation and the OP-Pohjola research foundation for the launching of the $\mathrm{OMaG}$ is gratefully acknowledged.

${ }^{\dagger}$ Corresponding author, contact information tel.: +358-40-485 6309, e-mail: JuhaPekka.Junttila@jyu.fi. Contact information for Marko Korhonen tel.: +358-8-44-5281270, fax +358-8-553 2906, e-mail: marko.korhonen@oulu.fi. Address for corresponding author: Jyväskylä University School of Business and Economics (JSBE), Department of Economics, Po Box 35, FI-40014 University of Jyväskylä, Finland. 
monetary models of Dornbusch (1976) and Frankel (1979), and especially of Meese and Rogoff (1988). The main message from the RERI approach ${ }^{1}$ is that the difference between the domestic and foreign real interest rates should be negatively correlated with the real exchange rate, when the nominal exchange rate is measured in units of domestic currency per one unit of foreign currency. This indicates that as the difference between the domestic and foreign real return on interest yielding assets increases, the value of the domestic currency appreciates $^{2}$.

Even though the RERI hypothesis appears reasonable in most models of the exchange rate, its empirical validity seems questionable. Baxter (1994) found some empirical evidence for the RERI relationship at trend and business-cycle frequencies during the floating-rate period of 1973 - 1991 for France, Germany, Japan, Switzerland, and the U.K., all pairwise analyzed against the U.S. Furthermore, her results indicated that the real interest differentials are related only to the temporary component of real exchange rates, and because most of the movement in real exchange rates seemed to be due to changes in the permanent component, the link was very weak. Nakagawa (2002) used a non-linear time series analytical approach to examine the RERI hypothesis, and found that only outside the so called 'band of inaction' (based on a transaction costinduced price adjustment), the real exchange rate behaves like a mean reverting variable and is associated to real interest differentials. Hoffman and MacDonald (2009) used the present value model approach of Campbell and Shiller (1987), and they were able to provide robust evidence that the RERI link is actually strong and the real interest rate differential strongly reflects the expected rate of currency depreciation over long horizons. They suggested that the RERI relationship should be interpreted more broadly as a significant and positive relationship between expected real exchange rate changes and the real interest rate differential. They also showed that a high fraction of the variability in interest rate differentials was actually explained by changes in the rate of expected depreciation.

The main innovation of our paper is to augment the original RERI relationship with stock market information. Solnik (1987) was among the first to introduce stock market data to exchange rate modelling ${ }^{3}$. The main finding in his paper was to realize the role of exchange rates as financial prices, which mimick the discounted value of all available information e.g. about the ex-

\footnotetext{
${ }^{1}$ Theoretical details of the original, pure RERI hypothesis are given in the next section.

${ }^{2}$ As emphasized by Baxter (1994), it is important to differentiate between the ex ante and ex post measures at this point. For example, in terms of ex ante values for the RERI, if the euro real exchange rate is above its long-run level against the U.S. dollar, the euro is expected to depreciate in real terms in the future, and to equate the ex ante real returns between the Euro area and the U.S., the ex ante real return on the euro-denominated securitites must exceed the corresponding return on the U.S. securities by the expected real devaluation of the euro over the term of the securities. Hence, there is a predicted link between the level of the real exchange rate and the ex ante relative real interest rate.

${ }^{3}$ For the more recent studies see e.g. Malliaropulos 1998, Hau and Rey 2006, Mercereau 2006, Andersen et al 2007, Pavlova and Rigobon 2007, Matsumoto et al 2008, and Engel and Matsumoto 2009.
} 
pected future real economic activity. He argued that if real economic activity is expected to improve in the near future, it should be immediately discounted in the exchange rate as well as in current stock prices. Furthermore, Solnik (1987) treated the changes in interest rates mainly as indicators of monetary shocks. Using monthly and quarterly observations for the period from 1973 to 1983 from Canada, France, Germany, Japan, the Netherlands, Switzerland, the U.K., and the U.S. he was able to find some evidence that the real exchange rates were affected by changes in the interest rate differentials, but not prior to 1979 at all. More importantly, especially in the period after September 1979, a positive relation between real stock return differentials and changes in the real exchange rate was evident.

We introduce the stock market information based on the long-run equilibrium relationships between goods, asset, and currency markets. The introduction of these equilibrium conditions ultimately leads us to conclude, that the relative dividend yield is the additional simple information variable to be included in the RERI analysis. Moreover, because here we always speak about long-run equilibrium relations in the analyzed markets, our empirical approach also utilizes only the highly familiar long-run method, i.e., cointegration analysis.

Our main result from the empirical analysis is that the poor empirical performance of both theoretically and empirically appealing real exchange rate-real interest rate parity clearly requires the inclusion of additional information from the stock markets. In sum, cointegration analyses applied to the data from the U.K, Japan, Canada (for the period of 19741:1 - 2008:9) and the Eurozone (for the 1991:1 - 2008:9 period), all calculated relatively to the U.S. market values, show that the stock market information based augmentation of the traditional RERI relationship is a relevant modification of the model especially in the shortterm (3-month) horizon. The role of additional information is evident already from the visual inspection of the data but our deeper cointegration and errorcorrection analysis clearly shows that all the relevant variables in the augmented RERI relationship have trended together over time and this finding challenges the traditional view of the RERI model. Already Baxter (1994) and Meese and Rogoff (1988) have suggested that some kind of addtional (real economy related) variables might have been omitted in the previous empirical analyses of the RERI hypothesis, and according to our results the relative dividend yield might be a valid candidate.

Our paper proceeds in the following way. In section 2 we give the theoretical background for the part of the traditional real interest parity and our idea on the augmentation of it using stock market information. Section 3 contains the description of the data and methods for the empirical analysis of the proposed augmentation, and section 4 gives details of the empirical results. Finally, in section 5 we report the main implications from our empirical evidence for the proposed role of stock market information in the analysis of the RERI hypothesis, and also sketch something for the future research agenda on this theme. 


\section{Theoretical background}

\subsection{The 'traditional' real interest rate parity}

Analogously to Meese and Rogoff (1988), Nakagawa (2002) and Hoffman and MacDonald (2009), we start our analysis from the uncovered interest rate parity (UIP) in the form

$$
E_{t}\left(s_{t+1}-s_{t}\right)=-\left(i_{t}^{*}-i_{t}\right),
$$

and we define the log of the real exchange rate $\left(\mathrm{q}_{t}\right)$ as $q_{t}=s_{t}+p_{t}^{*}-p_{t}$, where $s_{t}$ is the log of the nominal exchange rate (domestic currency per one unit of foreign currency), and $p_{t}^{*}$ and $p_{t}$ are logs of foreign and domestic price levels, respectively. $E_{t}$ denotes the expectations operator and $i_{t}^{*}$ and $i_{t}$ are foreign and domestic nominal interest rates. Define now the (expected) real interest rate differential as

$$
E_{t} \delta_{t+1} \equiv E_{t}\left(r_{t+1}^{*}-r_{t+1}\right)=\left(i_{t}^{*}-i_{t}\right)-E_{t}\left[\left(p_{t+1}^{*}-p_{t}^{*}\right)-\left(p_{t+1}-p_{t}\right)\right] .
$$

From this we get the real interest rate parity by subtracting the expected inflation differential from both sides of (1), i.e.,

$$
\begin{aligned}
& E_{t}\left(s_{t+1}-s_{t}\right)-E_{t}\left[\left(p_{t+1}-p_{t}\right)-\left(p_{t+1}^{*}-p_{t}^{*}\right)\right] \\
= & -\left(i_{t}^{*}-i_{t}\right)-E_{t}\left[\left(p_{t+1}-p_{t}\right)-\left(p_{t+1}^{*}-p_{t}^{*}\right)\right],
\end{aligned}
$$

resulting in $^{4}$

$$
E_{t} q_{t+1}-q_{t}=-E_{t}\left(r_{t+1}^{*}-r_{t+1}\right) .
$$

Now, because $E_{t}\left(r_{t+1}^{*}-r_{t+1}\right)=E_{t} \delta_{t+1}$, the previous equation gives us $E_{t} q_{t+1}-$ $q_{t}=-E_{t} \delta_{t+1}$, and hence, $q_{t}=E_{t} q_{t+1}+E_{t} \delta_{t+1}$. Forward iteration of this representation one period ahead and using the law of iterated expectations yields

$$
q_{t}=E_{t} q_{t+2}+E_{t} \delta_{t+1}+E_{t} \delta_{t+2},
$$

and for the $k$-period ahead case we obtain

$$
q_{t}=E_{t} q_{t+k}+E_{t} \delta_{t+1}+E_{t} \delta_{t+2}+\ldots+E_{t} \delta_{t+k} .
$$

For the very long-run horizon we may use the assumption that expectations of the real exchange rate are constant, i.e. $E_{t} q_{t+k}=\bar{q}$. This gives us now the representation

$$
q_{t}=\bar{q}+E_{t}\left[\sum_{j=0}^{k} \delta_{t+j}\right]=\bar{q}+E_{t}\left[\sum_{j=0}^{k}\left(r_{t+j}^{*}-r_{t+j}\right)\right],
$$

stating that the real exchange rate is comprised of the sum of future expected real interest rate differentials. This is the basic form of the RERI parity that has

\footnotetext{
${ }^{4}$ Note that we wish to define inflation differential here as the difference between the domestic and foreign inflation rates, because it suits better to equation (1), even though in the equation right above the diffrential is given the other way around.
} 
been analyzed empirically e.g. in Nakagawa (2002) and Mark and Moh (2005). In this paper we depart from previous studies and augment the real interest rate parity with stock market information given in the form of dividend yields (from the 'aggregate' stock markets of both the domestic and foreign countries). The theoretical background for this augmentation of the standard real interest rate parity is given next.

\subsection{Stock market information and the real exchange rate}

We start from the traditional stock market valuation model of Gordon (1962) in the form

$$
P_{t}^{S}=\frac{D_{t}}{i_{t}-g_{t+1}^{e}-\pi_{t+1}^{e}},
$$

where the current (time $t$ ) value of equity (stock price) is denoted by $P_{t}^{S}$, and $i_{t}$ is the nominal (short-term) interest rate at time $t, D_{t}$ is the dividend realized at time $t$, and $g_{t+1}^{e}$ is the expectation of the growth rate of economy for the next period (formed at time $t$ based on information at time $t$ ), reflecting also the growth possibilities of future real yields on stock market investments, and correspondingly, $\pi_{t+1}^{e}$ is the expected inflation rate for the next period at time $t$. Put simply, equation (3) states that in equilibrium the current stock price should be a discounted value of the expected future dividend conditional on the available information at time $t$.

Equation (3) can equally well be written in terms of the dividend yield, $d_{t}=D_{t} / P_{t}^{S}$, that is,

$$
d_{t}=i_{t}-g_{t+1}^{e}-\pi_{t+1}^{e} .
$$

Our representation at the moment involves two very frequently analyzed macroeconomic variables, namely the expected inflation and real growth of the economy. The role of stock and other financial market information in forecasting these two variables has recently been high on the research agendas of many leading economists, like James Stock and Mark Watson. Hence, in the spirit of their 2003 study (see Stock and Watson (2003) and the references therein), we next introduce two very familiar macroeconomic equilibrium conditions regarding these variables to our analysis. These are the Fisher (1930) equation

$$
i_{t}=r_{t+1}^{e}+\pi_{t+1}^{e}
$$

and the Euler equation ${ }^{5}$

$$
r_{t+1}^{e}=\rho+\lambda g_{t+1}^{e} \text {. }
$$

We add these as behavioral long-run equilibrium conditions, not just accounting identities, to the model. In addition to the previously defined variables, $\rho$ is the

\footnotetext{
${ }^{5}$ Put more precisely, our specification of the Euler equation follows the Romer (2006, p. 54 - 56) presentation for household behaviour, assuming that household consumption growth is strongly connected to the expectations of future aggregate economic activity (see also the introduction in Cochrane (2006)).
} 
rate of time preference, and $\lambda$ is the reciprocal of the intertemporal elasticity of substitution, both assumed to be constant over time.

After solving Fisher equation for the real interest rate we obtain

$$
r_{t+1}^{e}=i_{t}-\pi_{t+1}^{e}
$$

and after substituting this back to equation (3) we get for the domestic dividend yield a representation

$$
d_{t}=r_{t+1}^{e}-g_{t+1}^{e}
$$

and now by using Euler equation (6) we give the dividend yield in the form

$$
d_{t}=\rho-(1-\lambda) g_{t+1}^{e} .
$$

This can be solved for the expected growth rate for domestic country as

$$
g_{t+1}^{e}=\frac{\rho}{1-\lambda}-\frac{1}{1-\lambda} d_{t} .
$$

Moving towards an open economy extension we can equivalently present the expected growth rate for foreign country as

$$
g_{t+1}^{e *}=\frac{\rho}{1-\lambda}-\frac{1}{1-\lambda} d_{t}^{*},
$$

and based on Euler equations (separately for domestic and foreign countries) we can obtain the real interest rate differerential as

$$
r_{t+1}^{e}-r_{t+1}^{e *}=\lambda\left(g_{t+1}^{e}-g_{t+1}^{e *}\right) .
$$

Using (9) and (10) we get from this the real interest rate differential as

$$
r_{t+1}^{e}-r_{t+1}^{e *}=\frac{\lambda}{1-\lambda}\left(d_{t}^{*}-d_{t}\right)
$$

Now, by substituting (13) to equation (2) we get the following new presentation ${ }^{6}$ for real exchange rate changes:

$$
E_{t} q_{t+1}-q_{t}=\frac{\lambda}{1-\lambda}\left(d_{t}^{*}-d_{t}\right) .
$$

A dynamic relationship for the connection between the stock market information and real exchange rate based on equation (14) can be derived as follows. Let us define $\theta=\frac{\lambda}{1-\lambda}$ and $\eta_{t}=d_{t}^{*}-d_{t}$. Based on these notations we obtain from (14) a representation

$$
q_{t}=-\theta \eta_{t}+E_{t} q_{t+1}
$$

\footnotetext{
${ }^{6}$ A somewhat similar representation has previously been analysed by Malliaropulos (1998), but not by using the same kind of stock market information we emphasize, i.e. the dividend yield data.
} 
Forwarding this equation one period ahead we have

$$
q_{t+1}=-\theta \eta_{t+1}+E_{t+1} q_{t+2},
$$

and inserting this in equation (15) gives

$$
q_{t}=-\theta \eta_{t}+E_{t}\left(-\theta \eta_{t+1}+E_{t+1} q_{t+2}\right)=-\theta \eta_{t}+E_{t}\left(-\theta \eta_{t+1}\right)+E_{t} q_{t+2} .
$$

By continuing this forward iteration for $k$ periods (and using again the law of iterated expectations, i.e. that $E_{t}\left(E_{t+1}\left(x_{t+2}\right)=E_{t}\left(x_{t+2}\right)\right.$ etc.), we obtain the representation

$$
q_{t}=-\theta \eta_{t}+E_{t}\left(-\theta \eta_{t+1}\right)+E_{t}\left(\theta \eta_{t+2}\right)+\ldots+E_{t}\left(-\theta \eta_{t+k}\right)+E_{t} q_{t+k+1} .
$$

Assuming that in the long-run equilibrium $E_{t} q_{t+k+1}=\bar{q}$, i.e., that the expectations for the real exchange rate in the far distant future are constant ${ }^{7}$, we get the final representation for the dynamic relationship between the stock market information and the real exchange rate as

$$
q_{t}=\bar{q}+\left[-\theta E_{t} \sum_{j=0}^{k} \eta_{t+j}\right]=\bar{q}+\left(\frac{\lambda}{1-\lambda}\right) E_{t}\left[\sum_{j=0}^{k}\left(d_{t+j}^{*}-d_{t+j}\right)\right],
$$

implying that the values for the real exchange rate at time $t$ are partly composed of the sum of future dividend yield spreads. Hence, we propose that taking into account this potential relationship might be useful in empirical analyses of real interest rate parity, and help to resolve the previously observed mismatch of the theoretical ideas and empirical findings.

\subsection{Joining the real interest rate parity and stock market information}

The derivation of the final representation for the empirical analysis in this paper is based on combining the two above given partial equilibrium frameworks for the value of the real exchange rates. Hence, in addition to the effects based on the real interest rate differential we state that the values for real exchange rate at time $t$ are at least partly comprised of the sum of future dividend yield differentials. This gives us the final equation for the empirical analysis of an 'augmented' real interest rate parity in the form

$$
q_{t}=\text { constant }+E_{t}\left[\sum_{j=0}^{k}\left(r_{t+j}^{*}-r_{t+j}\right)\right]+\left(\frac{\lambda}{1-\lambda}\right) E_{t}\left[\sum_{j=0}^{k}\left(d_{t+j}^{*}-d_{t+j}\right)\right] \text {. }
$$

For the valid ranges of the regression coefficient on the (cumulative) dividend yield differential we obviously have numerous possibilities, all depending on the

\footnotetext{
${ }^{7}$ This is analogous to the flexible price equilibrium value.
} 
value of $\lambda$,so if we for example impose a restriction $\lambda /(\lambda-1)>0$, i.e., that $\lambda>1$ or $\lambda<-1$, the a priori assumptions for the effects of real interest rates and dividend yields are:

$$
\frac{\partial q_{t}}{\partial r_{t, k}}<0, \frac{\partial q_{t}}{\partial r_{t, k}^{*}}>0, \frac{\partial q_{t}}{\partial d_{t, k}}<0, \frac{\partial q_{t}}{\partial d_{t, k}^{*}}>0
$$

Hence, increasing values of either the domestic real interest rate or the domestic dividend yield have a depreciating effect on the value of the real exchange rate, and for the increasing values of the foreign variables the effect on the real exchange rate is appreciation. In addition, an obvious restriction for the regression analysis regarding the model given in (17) is that $\lambda \neq 1$ for the coefficient on the dividend yield difference to be well defined, implying also that the intertemporal elasticity of substitution should not be equal to one. In the empirical analysis we actually impose a viable restriction for the $\lambda$ to obtain the value of 3 , because this corresponds to the meaningful value of $1 / 3$ for the elasticity of substitution, based on some of the previous literature (e.g. Hall (1988)).

\section{Data and empirical methods}

We examine the empirical relationship between real exchange rates, relative real interest rates and relative dividend yields for four countries: the U.K., Japan, Canada and the Eurozone, and maintain the U.S. as the foreign counterpart for each country. The empirical analyses use monthly data and the sample period varies for each country depending on the availability of the data. For the UK, Japan and Canada the sample period is 1974:1 - 2008:9 and for the Eurozone the sample period is 1991:1 - 2008:9. The primary sources of data are the IMF's International Financial Statistics (IFS) and OECD Main Economic Indicators databases, but the dividend yield data are from Datastream ${ }^{8}$. When measured in levels, we convert all data except interest rates and dividend yields to log values, so the growth rates of each of the analyzed variables are measured by $\log$ differences.

Price levels are measured by consumer price indices (CPI), and the inflation rates are annual inflation rates, measured as the 12 -month $\log$ differences of CPIs. Short-term nominal interest rates are the 3-month money market rates (or "call money rates"). Exchange rates are defined against the U.S. dollar, and long-term interest rates are the 10 year bond yields. The real exchange rate is calculated by taking log values of the expression based on multiplying nominal spot bilateral exchange rates by foreign (U.S.) prices, that are divided

\footnotetext{
${ }^{8}$ In Datastream the dividend yield is calculated based on the equation $d_{t}=100\left[\left(\sum_{N=1}^{n} D_{t} N_{t}\right) /\left(\sum_{N=1}^{n} P_{t}^{S} N_{t}\right)\right.$, where $d_{t}$ is the aggregate dividend yield on day t (and we use the values for the last trading day in each month), $D_{t}$ is the dividend per share on day t, $N_{t}$ is the number of shares in issue on day t, $P_{t}^{S}$ is the unadjusted share price on day $\mathrm{t}$, and $n$ is the number of constituents in the index. The useful data on dividend yields for our purposes are calculated for the shares quoted only in the domestic market of each of the analyzed countries, and these series are available from Datastream.
} 
by domestic prices. The nominal exchange rates are defined as units per dollar, so an increase in nominal exchange rate indicates depreciation of the domestic currency and appreciation of the U.S. dollar. For the real interest rates and dividend yields we compute both ex ante and ex post values. For the ex post values we have assumed rational expectations with perfect foresight, and subtracted annualized realized 3-month CPI inflation rate from the short-term nominal interest rate and 36-month CPI inflation rate from the nominal long-term interest rate. For the calculation of ex ante real interest rates we first generated inflation expectations over a three month horizon for the short-term rates and over a three year horizon for the long-term rates. These procedures were based on running univariate rolling autoregressions for the CPI-inflation with appropriate lag structures in view of the Schwarz information criterion and the statistical significance of the AR-parameters in each case ${ }^{9}$.

To be exact, according to our theoretical model we need to calculate cumulative sums for relative real interest rates, $\sum\left(r^{*}-r\right)$, and relative dividend yields, $\sum\left(d^{*}-d\right)$, and these values are based on the cumulative sums for the short-term (3 month) and long-term (36 month) periods, both for the ex post and ex ante values. However, for comparison, we will also report the results based on point values of the 'explanatory' variables in our main regression equation regarding the most relevant parts of our analysis.

\section{Empirical results}

Table 1 presents a summary of descriptive and other statistics on the real exchange rates and ex ante and ex post measures of cumulative real interest rate and cumulative dividend yield differentials. Based on these results it would seem that the data generating processes (DGP) of all the analyzed series are highly persistent and have very high first order autocorrelation coefficients, which might indicate the presence of unit roots in the DGPs. The tests for unit roots were conducted without a deterministic trend, and the results indicated that the series mainly behave like unit root processes. However, in some cases the augmented Dickey-Fuller (1979)-test results based on the null of unit root were inconclusive with the Kwiatkowski-Phillips-Schmidt-Shinn (1992)-test results based on the null of stationarity. Especially for the real exchange rate series the test results were in favor of nonstationarity. The fact that the null of unit root could not be rejected for our main interesting variable indicates that deviations from PPP may have lasted a long time in this data set. Notice that Baxter (1994) has strongly argued that the real exchange rate should absolutely be a stationary variable, and the existence of permanent components in its DGP does not imply that the real exchange rate follows a random walk, i.e. that it is non-stationary, because in the long run there might be temporary

\footnotetext{
${ }^{9}$ The use of a 3-year period for the long-term (10 year) real rate calculations was based on the empirical finding that the expected values of inflation generated from the rolling ARprocedure did not change materially when moving from the 36 -month horizon to the longer horizons, so the 10 -year horizon values were very close to the 3 -year horizon values.
} 
(mean-reverting) components in the data as well. Nevertheless, based on our results from the preliminary descriptive statistics we clearly are able to argue that real exchange rates are quite persistent, and we might be forced to conclude that they are nonstationary in our data set ${ }^{10}$.

[Table 1 here]

On the other hand, regarding our new interesting variable in connection to the RERI analysis (the relative dividend yield) Ang and Bekaert (2007) present evidence that dividend yields and interest rates should also be stationary series. Based on these previous notes and discussions, in this paper we will proceed with our analysis by allowing for the possibility that all our variables may be either stationary or nonstationary in small samples, and examine all the relevant data both in levels and difference forms when we empirically analyze our proposed model. Furthermore, because our cumulative procedures for calculating the explanatory variables also involve overlapping mechanisms, especially for the long-run variables, the observed autocorrelation in some of our data series might be artificially generated. To control for these artificial persistence effects we also report the results from the cointegration analysis using the future point values for the explanatory variables.

When using the data in levels, we consider two different specifications. The first specification in table 2 is based on analyzing our version of the traditional RERI representation, involving only the real exchange rate and real interest rate differentials. The second specification, based on equation (17) given in the previous section, augments the traditional RERI hypothesis, and introduces the relative dividend yield to the analysis. The results reported in table 2 are designed to give a priori judgement for the validation of these two different regressions for the modeling of real exchange rate $^{11}$. The column titled 'Traditional RERI' reports the very simple OLS- regression results based on using only the relative real interest rate as the regressor. The column titled 'Augmented RERI' gives the results from the model, where the relative dividend yield is an additional regressor. We report the regression coefficients and test results from the F-tests for the validity of including the additional relative dividend yield variable to the model. In addition, as a proxy for the explanatory power of each of the competing specifications, and for the purposes of giving a quantitative measure for the observed validity of the models based on visual inspection in figure 1, we also report the cross correlation coefficient between the actual real exchange rates and the fitted values of each of the analyzed models, respectively. From the F-test results we see that the relative dividend yield is a significant additional regressor in almost all of our cases at the $1 \%$ significance level. Furthermore, simply by testing the statistical significance of the additional variable

\footnotetext{
${ }^{10}$ For similar kinds of arguments on the inference from the unit root test results for real exchange rates, see Engel (2000).

${ }^{11}$ For this kind of preliminary regression based analysis of parity-type relationships see Ang and Bekaert (2007).
} 
we find that the augmentation is useful in 13 cases out of 16 at the $5 \%$ level. Hence, we obtain preliminary support for the use of an augmented model instead of the traditional RERI presentation for our further analyses. Also based on the cross correlation coefficients the explanatory power of the augmented model clearly improves compared to the traditional representation.

[Figure 1 here]

[Table 2 here]

Based on our results in table 1 and in many previous papers (e.g. Meese and Rogoff 1988 and Edison and Pauls 1993), we next proceed to the stage allowing for the presence of unit roots in the analyzed time series processes. We use the Johansen (1988) multivariate cointegration system approach to test for cointegration between the variables in our model. The estimation results are based on a vector autoregressive (VAR) model with a constant term. The optimal lag lengths were chosen using the likelihood ratio statistics, and the residuals from the chosen VAR specifications were then checked for white noise characteristics implying the validity of the final representations. Our cointegration analysis for the augmented RERI model is based on a three variable vector error correction model (VECM), given in its general form as:

$$
\Delta z_{t}=\Pi z_{t-1}+\sum_{i=1}^{p} \Gamma_{i} \Delta z_{t-i}+\epsilon_{t},
$$

where $z_{t}=\left[q_{t}, \sum\left(r_{t+j}^{*}-r_{t+j}\right), \sum\left(d_{t+j}^{*}-d_{t+j}\right)\right], \Pi=\alpha \beta^{\prime}$, and $\alpha$ and $\beta$ are $3 \times 1$ vectors, whereas $\Gamma_{i}$ is a $3 \times 3$ matrix of parameters associated with $\Delta z_{t-i}$ in our application.

Table 3a reports the results from the cointegration analysis using the cumulative values of the right-hand-side (RHS) variables in equation (17). Again, we give the results for the traditional RERI model and for the augmented version of it. In most (that is, 12) of the 16 possible cases (comprising of 4 countries, for short- and long-term horizons, and for ex post and ex ante values of the explanatory variables) we were able to find one cointegrating vector in our augmented system at $10 \%$ risk level. When comparing the results between the traditional RERI model (where we were able to find cointegration in 8 out of 16 cases) and our augmented model, especially in the short term horizon, we were able to find cointegration in 7 cases out of 8 for the augmented model and only in 4 cases out of 8 for the traditional representation. Only for the Japanese ex ante short- and long-term, and the UK ex ante long-term data we were not able to detect any kind of cointegration between the analyzed variables. In the rest of the cases, for the long-term horizon we basically found no differences between the results for the traditional and augmented models, because cointegration was detected in five cases for both models. In sum, cointegration analyses showed that the stock market information based augmentation of the traditional RERI relationship is a relevant modification of the model especially in the short-term horizon. 
These results strengthen also our preliminary visual, and OLS-analysis based observation that the real exchange rate, relative cumulative real interest rates, and relative cumulative dividend yields have trended together over time and this finding challenges the traditional view of the RERI model. Baxter (1994) and Meese and Rogoff (1988) have suggested that some kind of real economic variables might have been omitted in the previous analyses of the RERI hypothesis, and according to our results already from this stage the relative dividend yield might be a valid candidate, especially for the short-term horizons.

[Table 3a here]

To control for the above mentioned possibility of artificial long-run comovement between the variables, we also conducted the cointegration tests using the (ex post and ex ante) point values of the RHS variables in the standard and augmented versions of the RERI. The use of point values is validated by the fact that most of the previous studies on the RERI relationship have used only the point values (see Meese and Rogoff 1988, Baxter 1994 and Hoffman and MacDonald 2009) in the empirical analysis. Table 3b reports the results from the cointegration analysis for the point values. Now we are able to find cointegration in 14 out of 16 cases for the augmented version at $10 \%$ risk level, and only for the UK ex post long-term and Japanese ex ante long-term data we were not able to find cointegration. On the other hand, for the traditional RERI representation we were able to find (a single) cointegration vector between the variables in only 6 cases out of the total of 16 . Hence, the results from point value data suggest even more strongly that the traditional RERI relationship needs augmentation, and based on our results we offer the relative dividend yield as a valid additional information variable. Furthermore, because the results based on point values of the RHS variables are even more suggestive of this augmentation, the results based on cumulative values do not seem to have suffered from any a priori advantage based on the cumulative calculation procedures for the analysis of the augmented model.

[Table 3b here]

Next we tested for the existence of plausible and relevant theoretical longrun economic relationships that the revealed single cointegration vector might reflect in each case. In particular, we tested for the hypothesis of cointegration:

i) between the real exchange rate and the other two variables, imposing first the one-to-one restriction on the relative real interest rate (implying the original 'strong form' RERI relationship), augmented by an unconstrained relative dividend yield effect, and an unconstrained constant term in the cointegration vector (version 1 in tables $4 \mathrm{a}$ and $4 \mathrm{~b}$ );

ii) based on the strong form RERI without stock market effects and the constant term in the cointegration vector (version 2 in tables $4 \mathrm{a}$ and $4 \mathrm{~b}$ );

iii) based on the strong from RERI augmented by constrained relative dividend yield effect (restriction based on assumed value of 0.33 for the intertempo- 
ral elasticity of substitution parameter), without a constant in the cointegration vector (version 3 in tables $4 \mathrm{a}$ and $4 \mathrm{~b}$ );

iv) based on version ii) plus an unconstrained constant in the cointegration vector (numbered column 4 in tables $4 \mathrm{a}$ and $4 \mathrm{~b}$; and finally,

v) based on version iii) plus an unconstrained constant in the cointegration vector (numbered column 5 in tables $4 \mathrm{a}$ and $4 \mathrm{~b}$ ).

[Table 4a here]

In general, the results reported in table $4 \mathrm{a}$ for the cumulative values of the RHS variables show that the most plausible hypotheses reflecting the validity of the final form of the augmented model represented by equation (17) (i.e., restrictions based on versions 1, 3 or 5 described above) are accepted in 6 out of 13 cases $^{12}$. According to the LR-statistics the hypotheses connected to the traditional RERI model (i.e., versions 2 and 4 ) are accepted in 5 cases out of 13 , but in all these the augmented model hypotheses were accepted, too, (in one form or the other) at $10 \%$ risk level. Column (6) in tables $4 \mathrm{a}$ and $4 \mathrm{~b}$ presents the restricted cointegration vector that would seem to be the most valid choice for each of the analyzed countries and horizons based on the reported LR-test statistics. Overall, for the restrictions regarding our theoretical model the most interesting cases are versions 1, 3 and 5, and in almost $50 \%$ of all the cases these restrictions seem to be valid in one form or the other.

[Table $4 \mathrm{~b}$ here]

The results are even more supportive for our theoretical model when we use the point values of the RHS variables in the analysis. From table $4 \mathrm{~b}$ we see that based on the reported LR-test statistics the augmented model is a valid representation in 12 out of 14 cases at $5 \%$ significance level. Only for the U.K. short-term ex post and Canadian long-term ex post data the augmented RERI model does not seem to be valid in the long-run, i.e. cointegration terms. However, for these cases the traditional RERI hypothesis was not accepted either, and the parameters of the cointegration vector do not satisfy any of our proposed economic restrictions, neither based on the traditional RERI nor the augmented version of it. Regardless of this the results based on using the point values for the RHS variables strongly support the inclusion of the relative dividend yield as an additional variable in the RERI analysis. Even though the introduction of this new variable is based on using fundamental long-run

\footnotetext{
${ }^{12}$ Our main decision rule in judging between the various restricted versions was that the most preferable representations are the ones where the most stringent restrictions on the most extensive (i.e., augmented) model are passed at the $5 \%$ significance level of the LR-test statistics. For example, when deciding between the most suitable cointegration vector for the Japanese ex-post long-term data, the choice was between versions (1) and (4) (see table 4a), and because the augmented model with freely estimated parameter values for the dividend yield spread and constant terms was clearly approved, we chose the representation based on Case 1 as the most preferable one.
} 
equilibrium conditions in the derivation of the augmented RERI model, the empirical results reveal that these conditions are mostly relevant for the shortterm, i.e., here the 3 -month data.

Our main result from the empirical analysis is that the poor empirical performance of the famous, and both theoretically and empirically appealing, real exchange rate-real interest rate parity calls for the introduction of additional information from the stock markets. Furthermore, from the long-term (i.e. longer than the money market maturities) perspective, even the introduction of the relative stock market performance information does not seem to be enough; the augmentation should perhaps be further deepened by including the information from the current accounts of the analyzed countries, as has been attempted in some of the previous studies in this area (see Wu 1999 and Edison and Melick 1999, and the introduction of this paper). However, because the short-term horizon results from our proposed, very simple stock market based augmentation seem to be highly encouraging, in our final notes we want to raise some questions regarding our cointegration results, that might call for more research and understanding in the future.

Because our main interest in this paper has been in simply revealing the role of stock market information in the functioning of the strong form RERI as a valid long-run equilibrium condition, as the final checks for the robustness of our results from the cointegration analysis the restrictions based on equation (17) were set to the error correction representations in all the cases where they seemed to be empirically relevant. This is based on the well known idea given by the Granger representation theorem, which states that if there is cointegration between a set of economic variables, it should be possible to examine their interaction using an error correction representation of the data, enabling one to extract the short-run effects from the long-run relationships. The results from this stage are reported in the Appendix, tables A1 - A4. These additional analyses reveal that the detected cointegration relationships might not have very strong short-run effects for the changes of the real exchange rate, and that even the causality between the analyzed variables is not uniquely defined in one way or the other.

Put more precisely, tests for Granger causality and weak exogeneity shed more light on the economic mechanisms apparent in the long-run empirical links between the variables. It is obvious that in view of our representation (17) the real exchange rate should behave as a leading variable for the right-hand side variables, because all the RHS variables are future values, irrespective of their calculation procedures (ex ante or ex post, point or cumulative values). However, the economic hypotheses behind the derivation of equation (17) stress the role of the exchange rate as a forward-looking variable, so from the point of view of our theoretical model, there should also be a causal relationship from the relative real interest rate and/or relative dividend yield towards the real exchange rate. In tables A1 - A4 we present the results on long-term causality, i.e. weak exogeneity for the levels of analyzed variables, and short-term causality, i.e. Granger causality for the differenced values, and we see that in many cases the Granger causality test results imply simultaneous relationships between all 
three analyzed variables of the augmented version of RERI. Furthermore, the hypothesis that changes in the real exchange rate do not Granger-cause changes in relative real interest rates is rejected in most of the cases, so there seems to be Granger causality from the real exchange rate to the relative interest rates, too. In addition to the tests on Granger causality we also tested for weak exogeneity between the analyzed variables. Tests for weak exogeneity are formal tests for the hypothesis that in equation (18) the values of the $\alpha$-parameter vector in the long-run matrix $\Pi$ are zero, and the test statistics are the LR statistics, which are $\chi^{2}(r)$ distributed under the null of weak exogeneity, where $r$ is the number of cointegration vectors. In a cointegrated system, if a variable does not respond to the discrepancy from the long-run equilibrium, it is called weakly exogenous. According to these additional results the real exchange rate might again not be the adjusting variable in the system.

\section{Conclusions}

Prior work on the relationship between the real exchange rate and real interest rate differential (RERI) has had difficulties in verifying the empirical link between these variables. In this study we augment the traditional RERI relationship with information on relative stock market performance. The augmentation relies on introducing a stock market equilibrium condition in the form of the simple Gordon (1962) valuation equation as the theoretical addition to the set of traditional long-run partial equilibrium concepts behind the RERI relationship. Based on our theoretical arguments, the proposed information variable is the relative dividend yield. In the empirical analysis we apply the cointegration method to recent monthly observations from the U.K., Japan, Canada and the Eurozone, all relative to U.S. data. Our main finding is that the introduction of stock market information in the form of relative dividend yields is highly relevant for the functioning of the RERI, at least when using the cointegration approach for the purpose of revealing the potential long-run economic relationships between the analyzed variables. Especially the results based on the point values for the relative real interest rates and relative dividend yields gave encouraging outcomes for our a priori theoretical arguments.

Put more precisely, the long-run comovement of the variables in the augmented RERI representation seems to be evident especially for the short-term (3 months) data. However, the revealed long-run economic relationship between the real exchange rate, real interest rate differentials and the dividend yield differentials does not seem to be uniquely adequate, at least in terms of the assumed causality from the financial markets to the currency market. This calls for more thorough analysis in future studies, and the future paths of research should concentrate on the possibilities of nonlinearities between the analyzed variables, and in their economic relationships. Furthermore, a natural next step in these type of exchange rate modelling studies would be the examination of the forecasting power of the analyzed, augmented model for the real exchange 
rate-real interest rate relationship. However, because our main purpose in this paper has only been in revealing the potential role of stock market based information in the RERI relationship, we leave these steps to be taken in our forthcoming studies. 


\section{References}

[1] Andersen, T. G., Bollerslev, T., Diebold, F.X., Vega, C., 2007. Real-time price discovery in global stock, bond and foreign exchange markets. Journal of International Economics 73, 251 - 277.

[2] Ang, A., Bekaert, G., 2007. Stock return predictability: Is it there? The Review of Financial Studies Vol 20 No 3, 651 - 707.

[3] Baxter, M., 1994. Real exchange rates and real interest differentials. Journal of Monetary Economics 33, 5 - 37.

[4] Campbell, J., Shiller, R., 1987. Cointegaration tests of present value models. Journal of Political Economy 95, 1062 - 1088.

[5] Coakley, J., Fuertes, A.-M., Wood, A., 2004. A new interpretation of the exchange rate-yield differential nexus. International Journal of Finance and Economics 9, 201 - 218.

[6] Cochrane, J., 2006. Financial markets and the real economy. Cheltenham, Edward Elgar.

[7] Devereux, M., B., Engel, C., 2006. Expectations and Exchange Rate Policy. NBER Working Paper No 12213

[8] Devereux, M., B., Engel, C., 2007. Expectations, Monetary Policy, and the Misalignment of Traded Goods Prices. NBER International Seminar on Macroeconomics 2007, 131-157.

[9] Dickey, D., Fuller, W. A., 1979. Distribution of the estimators for autoregressive time series with a unit root. Journal of The American Statistical Association 74, 427 - 431.

[10] Dornbusch, R., 1976. Expectations and exchange rate dynamics. Journal of Political Economy 84, 1161 - 1176.

[11] Edison, H.J., Melick, R. 1999. Alternative approaches to real exchange rates and real interest rates: Three up and three down. International Journal of Finance and Economics 4, 93 - 111.

[12] Engel, C., 2000. Long-run PPP may not hold after all. Journal of International Economics 51, 243 - 273.

[13] Engel, C., West, K. D., 2004. Accounting for exchange rate variability in present value models when the discount factor is near one. American Economic Review, Papers and Proceedings 94, 119-125.

[14] Engel, C., Matsumoto, A., 2009. The International Diversification Puzzle When Goods Pices Are Sticky: It's Really about Exchange-Rate Hedging, Not Equity Portfolios. American Economic Journal: Macroeconomics 1:2, $155-188$. 
[15] Fisher, I., 1930. The theory of interest. Reprint in 1965, New York, A.M. Kelley.

[16] Frankel, J., 1979: On the mark: A theory of floating exchange rates based on real interest differentials. American Economic Review 69, 610 - 622.

[17] Gordon, M. J., 1962. The investment, financing and valuation of the corporation. Illinois, Irwin Homewood.

[18] Hall R. E., 1988. Intertemporal Substitution in Consumption. Journal of Political Economcy 96, 339 - 357.

[19] Hau, H., Rey, H., 2006. Exchange Rates, Equity Prices, and Capital Flows. The Review of Financial Studies Vol 19 No 1, 273 - 317.

[20] Hoffmann, M., MacDonald, R., 2003. A re-examination of the link between real exchange rates and real interest rate differentials. CESIfo Working Paper No. 894.

[21] Hoffmann, M., MacDonald, R., 2009. Real exchange rates and real interest rate differentials: A present value interpretation. European Economic Review, in press.

[22] Johansen, S., 1988. Statistical analysis of cointegration vectors. Journal of Economic Dynamics and Control 12, 231 - 254.

[23] Kwiatkowski, D., Phillips, P.C.B., Schmidt, P., Shin, Y., 1992. Testing the null hypothesis of stationarity against the alternative of a unit root: How sure are we that economic time series are nonstanionary? Journal of Econometrics 54, 159 - 178.

[24] Malliaropulos, D., 1998. International stock return differentials and real exchange rate changes. Journal of International Money and Finance 17, $493-511$.

[25] Mark, N.C., Moh, Y.-K., 2005. The real exchange rate and real interest differentials: The role of nonlinearities. International Journal of Finance and Economics 10, 323 - 335.

[26] Mercereau, B., 2006. Stock markets and the real exchange rate: An intertemporal approach. Journal of International Money and Finance 25, $1130-1145$.

[27] Matsumoto, A., Cova, P., Pisani, M., Rebucci, A., 2008. New Shocks, Exchange Rates and Equity Prices. IMF Working Paper WP/08/284.

[28] Meese, R., Rogoff, K., 1988. Was it real? The exchange rate-interest differential relation over the modern floating-rate period. Journal of Finance 43, 933 - 948 . 
[29] Nakagawa, H., 2002. Real exchange rates and real interest differentials: Implications of nonlinear adjustment in real exchange rates. Journal of Monetary Economics 49, 629 - 649.

[30] Pavlova, A., Rigobon, R., 2007. Asset prices and exchange rates. The Review of Financial Studies Vol 20 No 4, 1139 - 1181.

[31] Romer, D., 2006. Advanced macroeconomics, 2nd ed. Irwin, McGraw-Hill.

[32] Solnik, B., 19987. Using financial prices to test exchange rate models: A note. Journal of Finance Vol XLII, No 1, 141 - 149.

[33] Sarno, L., 2005. Viewpoint: Towards a solution to the puzzles in exchange rate economics: where do we stand? Canadian Journal of Economics Vol 38 No $3,673-708$.

[34] Stock, J. H., Watson, M.W., 2003. Forecasting output and inflation: The role of asset prices. Journal of Economic Literature XLI, 788 - 829.

[35] Wu, J.-L., 1999. A re-examination of the exchange rate-interest differential relationship: Evidence from Germany and Japan. Journal of International Money and Finance 18, 319 - 336. 
Table 1:

\section{Descriptive Statistics}

Table 1 presents sample means, standard deviations and first order autocorrelation coefficients for the monthly time series of relevant variables. The sample period varies for each country depending on the availability of the data. For the UK, Japan and Canada the sample period is 1974:1 - 2008:9 and for the Eurozone it is 1991:1 - 2008:9. In addition to descriptive statistics we also report the results from augmented Dickey-Fuller-tests (ADF, $\mathrm{H}_{0}$ : unit root) and KwiatkowskiPhillips-Schmidt-Shin-tests (KPSS, $\mathrm{H}_{0}$ : stationarity), and the significance levels for both these test statistics are denoted by \# = $10 \%$, \#\# = $5 \%$, and \#\#\# $=1 \%$. All the relative (i.e., differential) values are calculated against the US market values. The analyzed variables are: Rex $=$ real exchange rate, Crideps $=$ cumulative real interest rate difference ex post short-term, Crideas $=$ cumulative real interest rate difference ex ante short-term, Cridepl $=$ cumulative real interest rate difference ex post long-term, Crideal = cumulative real interest rate difference ex ante long-term, and for the cumulative dividend yield differences Cdydeps, Cdydeas, Cdydepl, and Cdydeal refer to the corresponding values ex post and ex ante, and for short- and long-term horizons. The short-term horizon is 3 months, and long-term horizon is 36 months. In the calculation of ex ante values we use the generated values for inflation expectations over the three month horizon for the short term and three year horizon for the long term. These procedures were based on running univariate rolling autoregressions for the CPI-inflation with appropriate lag structures in view of e.g. the Schwarz information criteria and the statistical significance of the AR-parameters in each case.

\begin{tabular}{|c|c|c|c|c|c|c|c|c|c|}
\hline Country & Rex & Crideps & Crideas & Cridepl & Crideal & Cdydeps & Cdydeas & Cdydepl & Cdydeal \\
\hline \multicolumn{10}{|l|}{ UK } \\
\hline Mean & -.43 & -.27 & -.45 & -.25 & .09 & -.05 & -.05 & -.40 & -.42 \\
\hline Stdev & .14 & .18 & .09 & .59 & .32 & .03 & .03 & .23 & .14 \\
\hline Auto & .98 & .84 & .94 & .99 & .99 & .98 & .99 & .99 & .99 \\
\hline \multicolumn{10}{|c|}{ Test Statistics } \\
\hline $\mathrm{ADF}$ & $-2.65^{\#}$ & $-3.61^{\# \# \#}$ & -2.43 & $-3.02^{\# \#}$ & $-2.62^{\#}$ & -1.63 & -1.40 & -1.79 & $-3.06^{\# \#}$ \\
\hline KPSS & $2.97^{\# \# \#}$ & $.59^{\# \#}$ & $.41^{\#}$ & .30 & $.66^{\# \#}$ & $.62^{\# \#}$ & $1.49^{\#}$ & $5.59^{\# \# \#}$ & $4.27^{\# \# \#}$ \\
\hline \multicolumn{10}{|l|}{ Canada } \\
\hline Mean & .20 & -.06 & -.10 & -.45 & -.43 & .01 & .01 & -2.17 & .04 \\
\hline Stdev & .12 & .10 & .08 & .51 & .23 & .02 & .02 & .88 & .01 \\
\hline Auto & .99 & .84 & .96 & .99 & .99 & .99 & .99 & .99 & .99 \\
\hline \multicolumn{10}{|c|}{ Test Statistics } \\
\hline $\mathrm{ADF}$ & -2.32 & -2.43 & $-2.64^{\#}$ & -2.42 & -2.79 & -.82 & -1.42 & -2.40 & $-4.11^{\# \# \#}$ \\
\hline KPSS & $1.37^{\# \# \#}$ & .20 & .19 & $.46^{\# \#}$ & $3.26^{\# \# \#}$ & $1.23^{c}$ & $1.57^{\# \# \#}$ & $2.05^{\# \# \#}$ & $.49^{\# \#}$ \\
\hline \multicolumn{10}{|l|}{ Japan } \\
\hline Mean & .48 & .12 & .13 & .17 & .55 & .08 & .08 & .74 & .70 \\
\hline Stdev & .21 & .15 & .11 & .83 & .31 & .05 & .05 & .46 & .02 \\
\hline Auto & .99 & .86 & .97 & .99 & .99 & .99 & .99 & .99 & .99 \\
\hline \multicolumn{10}{|c|}{ Test Statistics } \\
\hline $\mathrm{ADF}$ & $-2.65^{\#}$ & -2.56 & -2.19 & $-4.51^{\# \# \#}$ & $-2.74^{\#}$ & -.42 & -.93 & -.94 & -2.28 \\
\hline KPSS & $1.15^{\# \# \#}$ & $1.19^{\# \# \#}$ & $1.26^{\# \# \#}$ & $.63^{\# \#}$ & $1.74^{\# \# \#}$ & $1.60^{\# \# \#}$ & $2.42^{\# \# \#}$ & $17.05^{\# \# \#}$ & $4.31^{\# \# \#}$ \\
\hline \multicolumn{10}{|l|}{ Eurozone } \\
\hline Mean & -.17 & -.04 & -.01 & -.44 & .53 & -.02 & -.03 & -.22 & -.32 \\
\hline Stdev & .14 & .09 & .05 & .43 & .14 & .02 & .01 & .13 & .01 \\
\hline Auto & .98 & .83 & .87 & .99 & .99 & .99 & .98 & .99 & .99 \\
\hline \multicolumn{10}{|c|}{ Test Statistics } \\
\hline $\mathrm{ADF}$ & -1.37 & $-2.79^{\# \#}$ & -2.54 & -1.59 & $-5.06^{\# \# \#}$ & -.68 & -.88 & -1.12 & $-2.69^{\#}$ \\
\hline KPSS & $1.99^{\# \# \#}$ & $.46^{\#}$ & .08 & $.55^{\# \#}$ & $.45^{\#}$ & $1.08^{\# \# \#}$ & $.54^{\# \#}$ & $7.51^{\# \# \#}$ & .13 \\
\hline
\end{tabular}


Table 2:

\section{Predictability of Real Exchange Rates}

Table 2 presents the OLS regression results from the regressions of real exchange rate $(\mathrm{q})$ on only the cumulative real interest rate differential $\left(\right.$ denoted $\left.r^{*}-r\right)$, i.e., the 'Traditional RERI', and alternatively, on both the cumulative real interest rate differential and the cumulative dividend yield differential $\left(d^{*}-d\right)$, the 'Augmented RERI'. The short-term horizon is 3 months, and long-term horizon is 36 months. We report the regression coefficients (with standard errors in parentheses) and the tests results from the F-tests for the adequacy of the augmented RERI including the additional relative dividend yield variable to the model. The significance levels for both the parameter estimates are denoted by \# = $10 \%$, \#\# = 5\%, and \#\#\#=1\%.We also report the joint correlation coefficients (CC) between the actual real exchange rates and the fitted values of both of the competing specifications, respectively.

\begin{tabular}{|c|c|c|c|c|c|c|}
\hline Country & Traditional RERI & \multicolumn{2}{|c|}{ Augmented RERI } & F-Test & $\mathrm{CC}$ & $\mathrm{CC}$ \\
\hline Short-term ex post & $r^{*}-r$ & $r^{*}-r$ & $d^{*}-d$ & & Trad. RERI & Augm. RERI \\
\hline UK & $\begin{array}{c}148^{\# \# \#} \\
(.04)\end{array}$ & $\begin{array}{c}.173^{\# \# \#} \\
(.04)\end{array}$ & $\begin{array}{c}1.152^{\# \# \#} \\
(.17)\end{array}$ & $15.18^{\# \# \#}$ & .11 & .27 \\
\hline Canada & $\begin{array}{c}.274_{(.06)}^{\# \# \#} \\
\text { \#\# }\end{array}$ & $\begin{array}{c}.252_{(.06)}^{\# \# \#} \\
\text { \#\# }\end{array}$ & $\begin{array}{c}-.716^{\# \# \#} \\
(.25)\end{array}$ & $3.81^{\# \#}$ & .22 & .31 \\
\hline Japan & $\begin{array}{l}.4655^{\# \# \#} \\
(.06)\end{array}$ & $\begin{array}{c}.337^{\# \# \#} \\
(.08)\end{array}$ & $\begin{array}{c}.595^{\# \# \#} \\
(.25)\end{array}$ & $5.69^{\# \# \#}$ & .26 & .31 \\
\hline Eurozone & $\begin{array}{c}.319^{\# \# \#} \\
(.09)\end{array}$ & $\begin{array}{c}.262^{\# \# \#} \\
(.09) \\
\end{array}$ & $\begin{array}{c}-1.931^{\# \# \#} \\
(.53)\end{array}$ & $9.40^{\# \# \#}$ & .18 & .32 \\
\hline \multicolumn{7}{|l|}{ Short-term ex ante } \\
\hline UK & $\begin{array}{c}174_{(.08)}^{\# \# \#} \\
\end{array}$ & $\begin{array}{c}-.147^{\# \# \#} \\
(.08)\end{array}$ & $\begin{array}{c}2.639 \# \# \# \\
(.28)\end{array}$ & $54.61^{\# \# \#}$ & -.12 & .38 \\
\hline Canada & $\begin{array}{c}312^{\# \# \#} \\
(.06)\end{array}$ & $\begin{array}{c}.321_{(.06)}^{\# \# \#} \\
\end{array}$ & $\begin{array}{c}-1.33^{\# \# \#} \\
(.24)\end{array}$ & 1.78 & .28 & .43 \\
\hline Japan & $\begin{array}{c}.564^{\# \# \#} \\
(.08)\end{array}$ & $\begin{array}{c}.308^{\# \# \#} \\
(.13)\end{array}$ & $\begin{array}{c}.738^{\# \# \#} \\
(.29)\end{array}$ & $6.49^{\# \# \#}$ & .26 & .33 \\
\hline Eurozone & $\begin{array}{c}-.443^{\# \#} \\
(.22) \\
\end{array}$ & $\begin{array}{c}-.199 \\
(.24) \\
\end{array}$ & $\begin{array}{c}-2.048^{\# \# \#} \\
(.88)\end{array}$ & $5.05^{\# \# \#}$ & .22 & .32 \\
\hline \multicolumn{7}{|l|}{ Long-term ex post } \\
\hline UK & $\begin{array}{l}.003 \\
(.01)\end{array}$ & $\begin{array}{l}.008 \\
(.01)\end{array}$ & $\begin{array}{c}.105^{\# \# \#} \\
(.03)\end{array}$ & $7.66^{\# \# \#}$ & -.08 & .11 \\
\hline Canada & $\begin{array}{l}.021 \\
.01)\end{array}$ & $\begin{array}{c}.084_{(.01)}^{\# \# \#} \\
\end{array}$ & .109 . & $14.25^{\# \# \#}$ & .08 & .56 \\
\hline Japan & $-.096^{\# \# \#}$ & $\begin{array}{c}-.041^{\# \# \#} \\
(.01)\end{array}$ & $\begin{array}{c}.326^{\# \# \#} \\
(.02)\end{array}$ & $28.59 \# \# \#$ & .23 & .75 \\
\hline Eurozone & $\begin{array}{c}.089^{\# \# \#} \\
(.03)\end{array}$ & $\begin{array}{c}-.271^{\# \# \#} \\
(.06)\end{array}$ & $\begin{array}{c}-1.61^{\# \# \#} \\
(.22)\end{array}$ & $51.84^{\# \# \#}$ & .19 & .65 \\
\hline \multicolumn{7}{|l|}{ Long-term ex ante } \\
\hline UK & $\begin{array}{c}-.042^{\#} \\
(.02)\end{array}$ & $\begin{array}{c}-.011^{\# \# \#} \\
(.02)\end{array}$ & $\begin{array}{c}3.289^{\# \# \#} \\
(.51)\end{array}$ & $27.54^{\# \# \#}$ & -.25 & .30 \\
\hline Canada & $\begin{array}{c}.259^{\# \# \#} \\
(.02)\end{array}$ & $\begin{array}{c}.258_{(.02)}^{\# \# \#} \\
\text { (.) }\end{array}$ & $-.232^{\# \# \#}$ & .10 & .54 & .54 \\
\hline Japan & $\begin{array}{c}.089^{\# \# \#} \\
(.04)\end{array}$ & $\begin{array}{c}.155^{\# \# \#} \\
(.03)\end{array}$ & $\begin{array}{c}7.662^{\# \# \#} \\
(.85)\end{array}$ & $77.56^{\# \# \#}$ & .17 & .53 \\
\hline Eurozone & $\begin{array}{c}-.355^{\# \# \#} \\
(.08) \\
\end{array}$ & $\begin{array}{c}-.021 \\
(.01) \\
\end{array}$ & $\begin{array}{c}-6.731^{\# \# \#} \\
(1.21) \\
\end{array}$ & 1.38 & -.01 & .22 \\
\hline
\end{tabular}


Table 3a:

\section{Results from the Johansen Cointegration Tests Using the Cumulative Values}

Table 3a presents results from the analysis based on the Johansen cointegration procedure for the cumulative values of the RHS variables in the RERI model. RERI indicates the standard real exchange rate - real interest rate parity version (including a constant) of the model, and Augm. RERI the model based on representation (25) given in the text. In table 3 we use the cumulative values like indicated in equation (17). The short-term horizon is 3 months and the long-term horizon is 36 months. Ex ante and ex post values are calculated based on the procedures described in the text and above table 1 . CI/no CI refers to the existence/nonexistence of cointegrating long-run relationships between the analyzed variables, and the figures in parentheses give the corresponding risk levels for the rejection of the null of no cointegration.

\begin{tabular}{lcccc}
\hline \hline Country & UK & Canada & Japan & Eurozone \\
\hline RERI model & \multicolumn{4}{c}{} \\
\hline $\begin{array}{l}\text { Short-term rates } \\
\text { ex-post }\end{array}$ & CI $(5 \%)$ & CI $(10 \%)$ & no CI & no CI \\
$\begin{array}{l}\text { ex-ante } \\
\text { Long-term rates } \\
\text { ex-post }\end{array}$ & no CI $(10 \%)$ & CI $(10 \%)$ & no CI & no CI \\
ex-ante & CI $(10 \%)$ & CI $(10 \%)$ & no CI & CI $(5 \%)$ \\
\hline Augm. RERI model & & & \\
\hline $\begin{array}{l}\text { Short-term rates } \\
\text { ex-post }\end{array}$ & CI $(1 \%)$ & CI $(10 \%)$ & CI $(10 \%)$ & CI $(10 \%)$ \\
$\begin{array}{l}\text { ex-ante } \\
\text { Long-term rates }\end{array}$ & CI $(10 \%)$ & CI $(10 \%)$ & no CI & CI $(10 \%)$ \\
\hline $\begin{array}{l}\text { ex-post } \\
\text { ex-ante }\end{array}$ & no CI & CI $(10 \%)$ & CI $(5 \%)$ & CI $(10 \%)$ \\
\hline \hline
\end{tabular}


Table 3b:

Results from the Johansen Cointegration Tests Using the Point Values

Table $3 \mathrm{~b}$ presents results from the analysis based on the Johansen cointegration procedure using the (ex-post and ex-ante) point values for the interest rate and dividend yield variables. RERI indicates the standard real exchange rate - real interest rate parity version (including a constant) of the model, and Augm. RERI the model based on representation (17) given in the text. See table 3a for the other notations

\begin{tabular}{lcccc}
\hline \hline Country & UK & Canada & Japan & Eurozone \\
\hline RERI model & & & & \\
\hline $\begin{array}{l}\text { Short-term rates } \\
\text { ex-post }\end{array}$ & CI $(1 \%)$ & CI $(1 \%)$ & no CI & CI $(1 \%)$ \\
ex-ante & CI $(10 \%)$ & CI $(10 \%)$ & no CI & no CI \\
$\begin{array}{l}\text { Long-term rates } \\
\text { ex-post }\end{array}$ & no CI & CI $(1 \%)$ & no CI & no CI \\
ex-ante & no CI & no CI & no CI & no CI \\
\hline Augm. RERI model & & & & \\
\hline $\begin{array}{l}\text { Short-term rates } \\
\text { ex-post }\end{array}$ & CI $(10 \%)$ & CI $(1 \%)$ & CI $(1 \%)$ & CI $(5 \%)$ \\
$\begin{array}{l}\text { ex-ante } \\
\text { Long-term rates }\end{array}$ & CI $(1 \%)$ & CI $(10 \%)$ & CI $(10 \%)$ & CI $(1 \%)$ \\
\hline $\begin{array}{l}\text { ex-post } \\
\text { ex-ante }\end{array}$ & no CI & CI $(1 \%)$ & CI $(1 \%)$ & CI $(1 \%)$ \\
\hline \hline
\end{tabular}


Table 4a:

Test Results for Economic Restrictions on the Cointegration Vectors Using the Cumulative Values

In table 4a we report the LR-test statistics (with corresponding P-values in the parentheses) for the tests on various possibilities for economic restrictions on the cointegration vector using the cumulative values for the RHS variables in equation (17) in the text. (1) refers to the case where the standard one-to-one RERI parity is spanning the cointegration space, whereas the parameter on the dividend yield differential $\left(\beta_{1}\right)$ is estimated freely, and so is the constant term $(c)$. Case (2) is the test for the standard RERI effect without the constant and stock market effects. In (3) in addition to the RERI effect the dividend yield differential effect is supposed to reflect a value of 0.33 for the elasticity of intertemporal substitution, EIS, (because $\lambda=3$ implies $\lambda /(1-\lambda)=-1.5$, where $\lambda$ is the inverse of EIS), and a zero constant term. Case (4) refers to the RERI parity without the stock market effect, but with constant term included to the cointegration vector. Case (5) refers to the situation, where in addition to the restricted stock market effect the constant term is allowed to be freely estimated. Finally, column (6) presents the parameters of cointegration vector that would seem to be the most valid ones based on the reported LR-test statistics on the identifying restrictions. The cointegration vector is always the same, i.e. $\left(q_{t-1}, r_{t-1}^{*}-r_{t-1}, d_{t-1}^{*}-d_{t-1}, c\right)^{\prime}$, where $q_{t-1}=$ the real exchange rate, $r_{t-1}^{*}-r_{t-1}$ $=$ the real interest rate differential, $d_{t-1}^{*}-d_{t-1}=$ the dividend yield differential (all these one period lagged values in levels), and $c=$ the constant term.

\begin{tabular}{|c|c|c|c|c|c|c|}
\hline Economic restrictions & $(1)$ & $(2)$ & $(3)$ & (4) & $(5)$ & $(6)$ \\
\hline Restr. on the $\beta^{\prime}$-vector & $\beta^{\prime}=\left[1,-1,-\beta_{1}, c\right]$ & $\beta^{\prime}=[1,-1,0,0]$ & $\beta^{\prime}=[1,-1,-1.5,0]$ & $\beta^{\prime}=[1,-1,0, c]$ & $\beta^{\prime}=[1,-1,-1.5, c]$ & Coefficients of the CI-vector \\
\hline \multicolumn{7}{|l|}{ Ex-post short-term } \\
\hline UK & $\begin{array}{l}19.79 \\
(0.00)\end{array}$ & $\begin{array}{l}30.59 \\
(0.00)\end{array}$ & $\begin{array}{l}27.38 \\
(0.00)\end{array}$ & $\begin{array}{l}23.81 \\
(0.00)\end{array}$ & $\begin{array}{l}20.02 \\
(0.00)\end{array}$ & $\begin{array}{c}\text { Free } \\
{[1,2.23,-7.86, .20]}\end{array}$ \\
\hline Canada & $\begin{array}{l}3.08 \\
(0.08)\end{array}$ & $\begin{array}{l}19.24 \\
(0.00)\end{array}$ & $\begin{array}{l}19.58 \\
(0.00)\end{array}$ & $\begin{array}{l}7.02 \\
(0.03)\end{array}$ & $\begin{array}{l}11.25 \\
(0.00)\end{array}$ & $\begin{array}{l}\text { Case } 1 \\
{[1,-1,2.68,-.28]}\end{array}$ \\
\hline Japan & $\begin{array}{l}4.78 \\
(0.02)\end{array}$ & $\begin{array}{l}12.50 \\
(0.00)\end{array}$ & $\begin{array}{l}12.60 \\
(0.00)\end{array}$ & $\begin{array}{l}4.80 \\
(0.09)\end{array}$ & $\begin{array}{l}5.44 \\
(0.07)\end{array}$ & $\begin{array}{c}\text { Case } 5 \\
{[1,-1,-1.5,-4.75]}\end{array}$ \\
\hline Eurozone & $\begin{array}{l}13.64 \\
(0.00)\end{array}$ & $\begin{array}{l}18.55 \\
(0.00)\end{array}$ & $\begin{array}{l}17.90 \\
(0.00)\end{array}$ & $\begin{array}{l}18.49 \\
(0.00)\end{array}$ & $\begin{array}{l}17.83 \\
(0.01)\end{array}$ & $\begin{array}{c}\text { Free } \\
{[1,2.65,16.59, .70]}\end{array}$ \\
\hline \multicolumn{7}{|l|}{ Ex-ante short-term } \\
\hline UK & $\begin{array}{l}.24 \\
(0.62)\end{array}$ & $\begin{array}{l}14.58 \\
(0.00)\end{array}$ & $\begin{array}{l}13.51 \\
(0.00)\end{array}$ & $\begin{array}{l}4.47 \\
(0.11)\end{array}$ & $\begin{array}{l}1.42 \\
(0.49)\end{array}$ & $\begin{array}{c}\text { Case } 5 \\
{[1,-1,-1.5, .33]}\end{array}$ \\
\hline Canada & $\begin{array}{l}5.80 \\
(0.02)\end{array}$ & $\begin{array}{l}19.18 \\
(0.00)\end{array}$ & $\begin{array}{l}19.31 \\
(0.00)\end{array}$ & $\begin{array}{l}13.69 \\
(0.00)\end{array}$ & $\begin{array}{l}19.71 \\
(0.00)\end{array}$ & $\begin{array}{c}\text { Free } \\
{[1,-2.52,5.98,-.47]}\end{array}$ \\
\hline Japan & na & na & na & na & na & na \\
\hline Eurozone & $\begin{array}{l}4.79 \\
(0.03)\end{array}$ & $\begin{array}{l}15.65 \\
(0.00) \\
\end{array}$ & $\begin{array}{l}15.16 \\
(0.00) \\
\end{array}$ & $\begin{array}{l}14.12 \\
(0.00) \\
\end{array}$ & $\begin{array}{l}14.14 \\
(0.00)\end{array}$ & $\begin{array}{c}\text { Free } \\
{[1,70.81,-177.99,-6.86]}\end{array}$ \\
\hline \multicolumn{7}{|l|}{ Ex-post long-term } \\
\hline UK & $\begin{array}{l}2.12 \\
(0.14)\end{array}$ & $\begin{array}{l}3.88 \\
(0.28)\end{array}$ & $\begin{array}{l}11.32 \\
(0.01)\end{array}$ & $\begin{array}{l}2.47 \\
(0.29)\end{array}$ & $\begin{array}{l}7.23 \\
(0.06)\end{array}$ & $\begin{array}{c}\text { Case 1 } \\
{[1,-1, .48, .46]}\end{array}$ \\
\hline Canada & $\begin{array}{l}7.04 \\
(0.01)\end{array}$ & $\begin{array}{l}14.79 \\
(0.00)\end{array}$ & $\begin{array}{l}11.29 \\
(0.01)\end{array}$ & $\begin{array}{l}9.82 \\
(0.00)\end{array}$ & $\begin{array}{l}8.04 \\
(0.03)\end{array}$ & $\begin{array}{c}\text { Free } \\
{[1,-.04,-.03,-.36]}\end{array}$ \\
\hline Japan & $\begin{array}{l}.11 \\
(0.74)\end{array}$ & $\begin{array}{l}13.47 \\
(0.00)\end{array}$ & $\begin{array}{l}17.19 \\
(0.00)\end{array}$ & $\begin{array}{l}.37 \\
(0.83)\end{array}$ & $\begin{array}{l}17.13 \\
(0.00)\end{array}$ & $\begin{array}{c}\text { Case } 1 \\
{[1,-1, .22,-4.82]}\end{array}$ \\
\hline Eurozone & $\begin{array}{l}4.96 \\
(0.03)\end{array}$ & $\begin{array}{l}13.40 \\
(0.00) \\
\end{array}$ & $\begin{array}{l}15.52 \\
(0.00) \\
\end{array}$ & $\begin{array}{l}11.97 \\
(0.00) \\
\end{array}$ & $\begin{array}{l}9.21 \\
(0.01) \\
\end{array}$ & $\begin{array}{c}\text { Free } \\
{[1, .11,1.16, .46]} \\
\end{array}$ \\
\hline \multicolumn{7}{|l|}{ Ex-ante long-term } \\
\hline UK & na & na & na & na & na & na \\
\hline Canada & $\begin{array}{l}0.02 \\
(0.88)\end{array}$ & $\begin{array}{l}13.47 \\
(0.00)\end{array}$ & $\begin{array}{l}13.02 \\
(0.00)\end{array}$ & $\begin{array}{l}.37 \\
(0.83)\end{array}$ & $\begin{array}{l}4.24 \\
(0.12)\end{array}$ & $\begin{array}{c}\text { Case } 5 \\
{[1,-1,-1.5,-.60]}\end{array}$ \\
\hline Japan & na & na & na & na & na & na \\
\hline Eurozone & $\begin{array}{l}4.69 \\
(0.03)\end{array}$ & $\begin{array}{l}41.93 \\
(0.00)\end{array}$ & $\begin{array}{l}41.60 \\
(0.00)\end{array}$ & $\begin{array}{l}12.54 \\
(0.00)\end{array}$ & $\begin{array}{l}13.36 \\
(0.00)\end{array}$ & $\begin{array}{c}\text { Free } \\
{[1,-10.91,28.33,3.16]}\end{array}$ \\
\hline
\end{tabular}


Table 4b:

Test Results for Economic Restrictions on the Cointegration Vectors Using the Point Values

In table $4 \mathrm{~b}$ we report the LR-test statistics (with corresponding P-values in the parentheses) for the tests on various possibilities for economic restrictions on the cointegration vector using the point values for the RHS variables in equation (17). For the description of notations see table 4 a.

\begin{tabular}{|c|c|c|c|c|c|c|}
\hline Economic restrictions & (1) & $(2)$ & (3) & (4) & $(5)$ & (6) \\
\hline Restr. on the $\beta^{\prime}$-vector & $\beta^{\prime}=\left[1,-1,-\beta_{1}, c\right]$ & $\beta^{\prime}=[1,-1,0,0]$ & $\beta^{\prime}=[1,-1,-1.5,0]$ & $\beta^{\prime}=[1,-1,0, c]$ & $\beta^{\prime}=[1,-1,-1.5, c]$ & Vector \\
\hline \multicolumn{7}{|l|}{ Ex-post short-term } \\
\hline UK & $\begin{array}{l}9.96 \\
(0.00)\end{array}$ & $\begin{array}{l}30.84 \\
(0.00)\end{array}$ & $\begin{array}{l}41.86 \\
(0.00)\end{array}$ & $\begin{array}{l}28.35 \\
(0.00)\end{array}$ & $\begin{array}{l}41.86 \\
(0.00)\end{array}$ & $\begin{array}{c}\text { Free } \\
{[1, .06,1.10,-.57]}\end{array}$ \\
\hline Canada & $\begin{array}{l}1.46 \\
(0.23)\end{array}$ & $\begin{array}{l}29.39 \\
(0.00)\end{array}$ & $\begin{array}{l}27.51 \\
(0.00)\end{array}$ & $\begin{array}{l}3.01 \\
(0.22)\end{array}$ & $\begin{array}{l}5.43 \\
(0.07)\end{array}$ & $\begin{array}{c}\text { Case } 5 \\
{[1,-1,-1.5,-1.47]}\end{array}$ \\
\hline Japan & $\begin{array}{l}2.27 \\
(0.13)\end{array}$ & $\begin{array}{l}56.86 \\
(0.00)\end{array}$ & $\begin{array}{l}68.26 \\
(0.00)\end{array}$ & $\begin{array}{l}42.32 \\
(0.00)\end{array}$ & $\begin{array}{l}68.14 \\
(0.00)\end{array}$ & $\begin{array}{c}\text { Case } 1 \\
{[1,-1,-1.80,-5.22]}\end{array}$ \\
\hline Eurozone & $\begin{array}{l}1.60 \\
(0.21)\end{array}$ & $\begin{array}{l}13.16 \\
(0.00)\end{array}$ & $\begin{array}{l}23.94 \\
(0.00)\end{array}$ & $\begin{array}{l}5.45 \\
(0.07)\end{array}$ & $\begin{array}{l}1.60 \\
(0.45)\end{array}$ & $\begin{array}{c}\text { Case } 5 \\
{[1,-1,-1.5,-1.90]}\end{array}$ \\
\hline \multicolumn{7}{|l|}{ Ex-ante short-term } \\
\hline UK & $\begin{array}{l}.24 \\
(0.62)\end{array}$ & $\begin{array}{l}8.90 \\
(0.03)\end{array}$ & $\begin{array}{l}25.78 \\
(0.00)\end{array}$ & $\begin{array}{l}6.80 \\
(0.03)\end{array}$ & $\begin{array}{l}17.43 \\
(0.00)\end{array}$ & $\begin{array}{c}\text { Case } 1 \\
{[1,-1,1.44,1.08]}\end{array}$ \\
\hline Canada & $\begin{array}{l}2.25 \\
(0.13)\end{array}$ & $\begin{array}{l}15.89 \\
(0.00)\end{array}$ & $\begin{array}{l}18.90 \\
(0.00)\end{array}$ & $\begin{array}{l}4.84 \\
(0.09)\end{array}$ & $\begin{array}{l}12.00 \\
(0.00)\end{array}$ & $\begin{array}{c}\text { Case } 1 \\
{[1,-1,1.38,-2.55]}\end{array}$ \\
\hline Japan & $\begin{array}{l}.58 \\
(0.45)\end{array}$ & $\begin{array}{l}21.57 \\
(0.00)\end{array}$ & $\begin{array}{l}23.61 \\
(0.00)\end{array}$ & $\begin{array}{l}18.64 \\
(0.00)\end{array}$ & $\begin{array}{l}22.58 \\
(0.00)\end{array}$ & $\begin{array}{c}\text { Case } 1 \\
{[1,-1,1.79,-4.99]}\end{array}$ \\
\hline Eurozone & $\begin{array}{l}4.07 \\
(0.04)\end{array}$ & $\begin{array}{l}6.24 \\
(0.10) \\
\end{array}$ & $\begin{array}{l}10.89 \\
(0.01) \\
\end{array}$ & $\begin{array}{l}5.39 \\
(0.07) \\
\end{array}$ & $\begin{array}{l}8.61 \\
(0.01) \\
\end{array}$ & $\begin{array}{c}\text { Case } 1 \\
{[1,-1,1.10,1.12]} \\
\end{array}$ \\
\hline \multicolumn{7}{|l|}{ Ex-post long-term } \\
\hline UK & na & na & na & na & na & na \\
\hline Canada & $\begin{array}{l}9.69 \\
(0.00)\end{array}$ & $\begin{array}{l}32.54 \\
(0.00)\end{array}$ & $\begin{array}{l}13.28 \\
(0.08)\end{array}$ & $\begin{array}{l}23.56 \\
(0.00)\end{array}$ & $\begin{array}{l}68.80 \\
(0.00)\end{array}$ & $\begin{array}{c}\text { Free } \\
{[1,-.10,-.18,-2.17]}\end{array}$ \\
\hline Japan & $\begin{array}{l}1.18 \\
(0.28)\end{array}$ & $\begin{array}{l}17.61 \\
(0.00)\end{array}$ & $\begin{array}{l}7.54 \\
(0.06)\end{array}$ & $\begin{array}{l}5.93 \\
(0.05)\end{array}$ & $\begin{array}{l}5.67 \\
(0.06)\end{array}$ & $\begin{array}{c}\text { Case } 5 \\
{[1,-1,-1.5,-.46]}\end{array}$ \\
\hline Eurozone & $\begin{array}{l}1.60 \\
(0.21)\end{array}$ & $\begin{array}{l}13.16 \\
(0.00)\end{array}$ & $\begin{array}{l}23.99 \\
(0.00)\end{array}$ & $\begin{array}{l}5.45 \\
(0.07)\end{array}$ & $\begin{array}{r}1.60 \\
(0.45)\end{array}$ & $\begin{array}{c}\text { Case } 5 \\
{[1,-1,-1.5,-1.93]}\end{array}$ \\
\hline \multicolumn{7}{|l|}{ Ex-ante long-term } \\
\hline UK & $\begin{array}{l}.35 \\
(0.55)\end{array}$ & $\begin{array}{l}10.44 \\
(0.02)\end{array}$ & $\begin{array}{l}12.97 \\
(0.00)\end{array}$ & $\begin{array}{l}5.87 \\
(0.05)\end{array}$ & $\begin{array}{l}5.64 \\
(0.06)\end{array}$ & $\begin{array}{c}\text { Case } 5 \\
{[1,-1,-1.5,-1.04]}\end{array}$ \\
\hline Canada & $\begin{array}{l}0.08 \\
(0.78)\end{array}$ & $\begin{array}{l}28.26 \\
(0.00)\end{array}$ & $\begin{array}{l}28.03 \\
(0.00)\end{array}$ & $\begin{array}{l}22.19 \\
(0.00)\end{array}$ & $\begin{array}{l}22.30 \\
(0.00)\end{array}$ & $\begin{array}{c}\text { Case } 1 \\
{[1,-1,218.9,-25.26]}\end{array}$ \\
\hline Japan & na & na & na & na & na & na \\
\hline Eurozone & $\begin{array}{l}1.65 \\
(0.20)\end{array}$ & $\begin{array}{l}37.74 \\
(0.00) \\
\end{array}$ & $\begin{array}{l}35.29 \\
(0.00) \\
\end{array}$ & $\begin{array}{l}31.92 \\
(0.00)\end{array}$ & $\begin{array}{l}31.10 \\
(0.00)\end{array}$ & $\begin{array}{c}\text { Case } 1 \\
{[1,-1,66.3,57.6]} \\
\end{array}$ \\
\hline
\end{tabular}




\section{Table A1:}

\section{Results from the Causality Tests for the Short-Term Data Using Cumulative Values}

In table A1 we give the results from testing Granger causality and weak exogeneity in the short-term (3 months) data using the cumulative RHS variable values. We also report the $\alpha$-parameter values, i.e., the error correction coefficients based on representation (18) in the text. The short-run Granger causality test results refer to the F-test statistics (where the null is no Granger causality) and the results on long-run causality, i.e., weak exogeneity are based on the LR-test statistics that follow a $\chi^{2}$-distribution under the null of one valid cointegration vector that affects the differenced values of the analyzed variables in the estimated three-variable VECM. The optimal lag lengths in the VAR representations for the causality tests vary from 1 to 14 , and are based on Schwarz information criteria. The significance levels for all the test statistics are denoted by $\#=10 \%$, \#\#=5\%, and \#\#\#=1\%. The variables in the VAR are $\Delta q=$ change in the real exchange rate, $\Delta\left(r^{*}-r\right)=$ change in the relative cumulative real interest rate, and $\Delta\left(d^{*}-d\right)=$ change in the relative cumulative dividend yield.

\begin{tabular}{|c|c|c|c|c|c|c|c|c|c|c|c|}
\hline Country & & anger Caus & $\overline{l i t y}$ & Weak Ex. & $\alpha$ & Country & & anger Caus & ity & Weak Ex. & $\alpha$ \\
\hline UK, ex post & $\Delta q$ & $\Delta\left(r^{*}-r\right)$ & $\Delta\left(d^{*}-d\right)$ & & & UK, ex ante & $\Delta q$ & $\Delta\left(r^{*}-r\right)$ & $\Delta\left(d^{*}-d\right)$ & & \\
\hline$\Delta q$ & $7.03^{\# \# \#}$ & $4.59^{\# \# \#}$ & .71 & 1.38 & -.005 & $\Delta q$ & $4.27 \# \# \#$ & 1.06 & .84 & $3.92^{\# \#}$ & $-.034^{\# \# \#}$ \\
\hline$\Delta\left(r^{*}-r\right)$ & 1.07 & $45.08^{\# \# \#}$ & $2.57^{\# \# \#}$ & $12.47^{\# \# \#}$ & $-.048^{\# \# \#}$ & $\Delta\left(r^{*}-r\right)$ & 1.49 & $46.77^{\# \# \#}$ & 1.43 & .48 & -.004 \\
\hline$\Delta\left(d^{*}-d\right)$ & .51 & 1.91 & $111.33^{\# \# \#}$ & $9.62^{\# \# \#}$ & $.095^{\# \# \#}$ & $\Delta\left(d^{*}-d\right)$ & 1.06 & 1.35 & $56.17^{\# \# \#}$ & 1.06 & .000 \\
\hline Canada, ex post & & & & & & Canada, ex ante & & & & & \\
\hline$\Delta q$ & $3.78^{\# \# \#}$ & $2.65^{\# \# \#}$ & 1.35 & .30 & -.007 & $\Delta q$ & $3.85^{\# \# \#}$ & 1.21 & .86 & .28 & .003 \\
\hline$\Delta\left(r^{*}-r\right)$ & $1.62^{\#}$ & $18.87^{\# \# \#}$ & .52 & $11.33^{\# \# \#}$ & $.046^{\# \# \#}$ & $\Delta\left(r^{*}-r\right)$ & 1.07 & $24.91^{\# \# \#}$ & $1.96^{\#}$ & $12.57^{\# \# \#}$ & .020 \\
\hline$\Delta\left(d^{*}-d\right)$ & .62 & $2.39^{\# \# \#}$ & $48.32^{\# \# \#}$ & $4.04^{\# \#}$ & $-.002^{\# \# \#}$ & $\Delta\left(d^{*}-d\right)$ & .67 & $2.35^{\# \# \#}$ & $56.57^{\# \# \#}$ & $5.99^{\# \#}$ & $-.001^{\# \# \#}$ \\
\hline Japan, ex post & & & & & & Japan, ex ante & & & & & \\
\hline$\Delta q$ & $4.68^{\# \# \#}$ & $2.80^{\# \# \#}$ & $2.09^{\# \# \#}$ & $3.09^{\#}$ & -.009 & $\Delta q$ & na & na & na & na & na \\
\hline$\Delta\left(r^{*}-r\right)$ & 1.43 & $25.65^{\# \# \#}$ & $1.85^{\# \#}$ & 1.24 & -.007 & $\Delta\left(r^{*}-r\right)$ & na & na & na & na & na \\
\hline$\Delta\left(d^{*}-d\right)$ & 1.17 & .78 & 49.91\#\#\# & $6.68^{\# \#}$ & $.001^{\# \# \#}$ & $\Delta\left(d^{*}-d\right)$ & na & na & na & na & na \\
\hline Eurozone, ex post & & & & & & Eurozone, ex ante & & & & & \\
\hline$\Delta q$ & $3.92^{\# \# \#}$ & $2.13^{\# \# \#}$ & 1.42 & .58 & .004 & $\Delta q$ & $2.18^{\# \#}$ & 1.14 & .94 & .00 & .001 \\
\hline$\Delta\left(r^{*}-r\right)$ & $2.17^{\# \#}$ & $23.42^{\# \# \#}$ & 1.34 & .99 & $-.016^{\# \# \#}$ & $\Delta\left(r^{*}-r\right)$ & 1.01 & $18.36^{\# \# \#}$ & 1.10 & 1.91 & .001 \\
\hline$\Delta\left(d^{*}-d\right)$ & $3.41^{\# \# \#}$ & $3.36^{\# \# \#}$ & $44.03^{\# \# \#}$ & $16.54^{\# \# \#}$ & $-.001^{\# \# \#}$ & $\Delta\left(d^{*}-d\right)$ & 1.65 & .71 & $18.52^{\# \# \#}$ & $4.82^{\# \#}$ & $-.01^{\# \# \#}$ \\
\hline
\end{tabular}


Table A2:

\section{Results from the Causality Tests for the Short-Term Data Using Point Values}

In table A2 we give the results from testing Granger causality and weak exogeneity in the short-run (3 months) data using the point values for the RHS variables in equation (17). We also report the $\alpha$-parameter values, i.e., the error correction coefficients based on representation (18) in the text. The short-run Granger causality test results refer to the F-test statistics (where the null is no Granger causality) and the results on long-run causality, i.e., weak exogeneity are based on the LR-test statistics that follow a $\chi^{2}$-distribution under the null of one valid cointegration vector that affects the differenced values of the analyzed variables in the estimated three-variable VECM. The optimal lag lengths in the VAR representations for the causality tests vary from 1 to 14 , and are based on Schwarz information criteria. The significance levels for all the test statistics are denoted by \# = 10\%, \#\#= $5 \%$, and \#\#\# = $1 \%$. The variables in the VAR are $\Delta q=$ change in the real exchange rate, $\Delta\left(r^{*}-r\right)=$ change in the relative real interest rate, and $\Delta\left(d^{*}-d\right)=$ change in the relative dividend yield.

\begin{tabular}{|c|c|c|c|c|c|c|c|c|c|c|c|}
\hline Country & & inger Causa & & Weak Ex. & $\bar{\alpha}$ & Country & & nger Causa & & Weak Ex. & $\bar{\alpha}$ \\
\hline UK, ex post & $\Delta q$ & $\Delta\left(r^{*}-r\right)$ & $\Delta\left(d^{*}-d\right)$ & & & UK, ex ante & $\Delta q$ & $\Delta\left(r^{*}-r\right)$ & $\Delta\left(d^{*}-d\right)$ & & \\
\hline$\Delta q$ & $6.65^{\# \# \#}$ & $4.16^{\# \# \#}$ & 1.20 & 1.52 & -.000 & $\Delta q$ & $8.75^{\# \# \#}$ & 1.77 & $2.36^{\#}$ & $6.63^{\# \# \#}$ & $.002^{\# \# \#}$ \\
\hline$\Delta\left(r^{*}-r\right)$ & 1.24 & $31.69^{\# \# \#}$ & $4.27^{\# \# \#}$ & $5.85^{\# \#}$ & .47 & $\Delta\left(r^{*}-r\right)$ & .54 & $5.53^{\# \# \#}$ & $2.21^{\#}$ & $20.79^{\#}$ & $-.278^{\# \# \#}$ \\
\hline$\Delta\left(d^{*}-d\right)$ & .27 & .89 & $2.96^{\# \# \#}$ & $40.85^{\# \# \#}$ & $-.035^{\# \# \#}$ & $\Delta\left(d^{*}-d\right)$ & .86 & 1.16 & $5.20^{\# \# \#}$ & 1.70 & .008 \\
\hline Canada, ex post & & & & & & Canada, ex ante & & & & & \\
\hline$\Delta q$ & $8.84^{\# \# \#}$ & $9.57^{\# \# \#}$ & .19 & 2.32 & .100 & $\Delta q$ & $6.08^{\# \# \#}$ & .62 & .60 & .44 & .000 \\
\hline$\Delta\left(r^{*}-r\right)$ & 1.31 & $4.11^{\# \# \#}$ & .89 & $88.84^{\# \# \#}$ & $-.61^{\# \# \#}$ & $\Delta\left(r^{*}-r\right)$ & $2.37^{\#}$ & $20.71^{\# \# \#}$ & .35 & $19.10^{\# \# \#}$ & $.191^{\# \# \#}$ \\
\hline$\Delta\left(d^{*}-d\right)$ & .25 & $4.10^{\# \# \#}$ & $3.08^{\# \# \#}$ & $.436^{\# \#}$ & $-.009^{\# \# \#}$ & $\Delta\left(d^{*}-d\right)$ & .66 & $3.45^{\# \#}$ & $5.20^{\# \# \#}$ & $4.66^{\# \#}$ & $-.007 \# \# \#$ \\
\hline Japan, ex post & & & & & & Japan, ex ante & & & & & \\
\hline$\Delta q$ & $9.71^{\# \# \#}$ & $4.97^{\# \# \#}$ & .99 & 1.12 & .000 & $\Delta q$ & $17.79^{\# \# \#}$ & .53 & $2.99^{\#}$ & .71 & $-.004^{\# \# \#}$ \\
\hline$\Delta\left(r^{*}-r\right)$ & $2.01^{\#}$ & $4.34^{\# \# \#}$ & .34 & $90.92^{\# \# \#}$ & $1.08^{\# \# \#}$ & $\Delta\left(r^{*}-r\right)$ & .81 & 2.18 & .76 & 2.10 & .038 \\
\hline$\Delta\left(d^{*}-d\right)$ & .63 & 1.94 & .98 & $7.57^{\# \#}$ & $.006^{\# \# \#}$ & $\Delta\left(d^{*}-d\right)$ & 2.12 & .10 & 2.87 & $5.44^{\# \#}$ & .00 \\
\hline Eurozone, ex post & & & & & & Eurozone, ex ante & & & & & \\
\hline$\Delta q$ & $19.38^{\# \# \#}$ & $6.97^{\# \# \#}$ & .99 & $6.39^{\# \# \#}$ & -.001 & $\Delta q$ & $2.97^{\# \#}$ & .45 & 1.31 & 1.09 & $-.003^{\#}$ \\
\hline$\Delta\left(r^{*}-r\right)$ & $2.58^{\#}$ & .75 & .65 & $55.00^{\# \# \#}$ & $.71^{\# \# \#}$ & $\Delta\left(r^{*}-r\right)$ & .51 & $6.34^{\# \# \#}$ & 1.03 & $6.44^{\# \#}$ & $.348^{\# \# \#}$ \\
\hline$\Delta\left(d^{*}-d\right)$ & .23 & .85 & .69 & 1.03 & .001 & $\Delta\left(d^{*}-d\right)$ & 1.25 & 1.23 & 1.75 & $9.18^{\# \#}$ & $-.030^{\# \# \#}$ \\
\hline
\end{tabular}


Table A3:

\section{Results from the Causality Tests for the Long-Term Data Using Cumulative Values}

In table A3 we give the results from testing Granger causality and weak exogeneity in the long-term (36 months) data using the cumulative values for the RHS variables. See table A1 for the variable notations and description of all the reported test statistics.

\begin{tabular}{|c|c|c|c|c|c|c|c|c|c|c|c|}
\hline Country & & anger Caus: & & Weak Ex. & $\overline{\alpha \alpha}$ & Country & & ranger Caus & lity & Weak Ex. & $\overline{\alpha \alpha}$ \\
\hline UK, ex post & $\Delta q$ & $\Delta\left(r^{*}-r\right)$ & $\Delta\left(d^{*}-d\right)$ & & & UK, ex ante & $\Delta q$ & $\Delta\left(r^{*}-r\right)$ & $\Delta\left(d^{*}-d\right)$ & & \\
\hline$\Delta q$ & $3.42^{\# \# \#}$ & 1.20 & 1.00 & .24 & $-.005^{\# \#}$ & $\Delta q$ & na & na & na & na & na \\
\hline$\Delta\left(r^{*}-r\right)$ & $1.59^{\#}$ & $11.97 \# \# \#$ & $3.25^{\# \# \#}$ & $2.83^{\#}$ & $.017^{\# \#}$ & $\Delta\left(r^{*}-r\right)$ & na & na & na & na & na \\
\hline$\Delta\left(d^{*}-d\right)$ & .53 & 1.24 & $99.22^{\# \# \#}$ & 1.38 & .000 & $\Delta\left(d^{*}-d\right)$ & na & na & na & na & na \\
\hline Canada, ex post & & & & & & Canada, ex ante & & & & & \\
\hline$\Delta q$ & $2.16^{\#}$ & .54 & 1.45 & 1.14 & -.007 & $\Delta q$ & $4.61^{\# \# \#}$ & 1.23 & .87 & 1.72 & -.007 \\
\hline$\Delta\left(r^{*}-r\right)$ & .19 & 1.52 & $5.48^{\# \# \#}$ & $5.18^{\# \#}$ & $-.090^{\# \# \#}$ & $\Delta\left(r^{*}-r\right)$ & .63 & 43.04\#\#\# & 1.16 & 1.20 & .027 \\
\hline$\Delta\left(d^{*}-d\right)$ & .92 & $4.19^{\# \# \#}$ & $124.61^{\# \# \#}$ & $5.67^{\# \#}$ & $-.005^{\# \# \#}$ & $\Delta\left(d^{*}-d\right)$ & $2.27^{\#}$ & .79 & $279.82^{\# \# \#}$ & 2.29 & .000 \\
\hline Japan, ex post & & & & & & Japan, ex ante & & & & & \\
\hline$\Delta q$ & $22.58^{\# \# \#}$ & .59 & $3.53^{\# \# \#}$ & 1.52 & $-.004^{\# \# \#}$ & $\Delta q$ & na & na & na & na & na \\
\hline$\Delta\left(r^{*}-r\right)$ & 1.61 & 2.29 & $4.68^{\# \# \#}$ & $13.78^{\# \# \#}$ & $.026^{\# \# \#}$ & $\Delta\left(r^{*}-r\right)$ & na & na & na & na & na \\
\hline$\Delta\left(d^{*}-d\right)$ & 1.02 & $3.59^{\# \# \#}$ & $104.91^{\# \# \#}$ & .03 & .000 & $\Delta\left(d^{*}-d\right)$ & na & na & na & na & na \\
\hline Eurozone, ex post & & & & & & Eurozone, ex ante & & & & & \\
\hline$\Delta q$ & $13.16^{\# \# \#}$ & .009 & 2.25 & $6.93^{\# \# \#}$ & -.043 & $\Delta q$ & $9.89^{\# \# \#}$ & 2.10 & $3.41^{\# \# \#}$ & .01 & $-.003^{\#}$ \\
\hline$\Delta\left(r^{*}-r\right)$ & 1.74 & 1.32 & $11.70^{\# \# \#}$ & 1.96 & .062 & $\Delta\left(r^{*}-r\right)$ & $6.95^{\# \# \#}$ & $19.26^{\# \# \#}$ & .92 & $14.13^{\# \# \#}$ & $.001^{\# \# \#}$ \\
\hline$\Delta\left(d^{*}-d\right)$ & 1.01 & .19 & $45.02^{\# \# \#}$ & 2.68 & $-.003^{\# \# \#}$ & $\Delta\left(d^{*}-d\right)$ & 2.10 & $2.83^{\# \#}$ & $6.61^{\# \# \#}$ & $11.42^{\# \# \#}$ & $-.002^{\# \# \#}$ \\
\hline
\end{tabular}


Table A4:

Results from the Causality Tests for the Long-Term Data Using Point Values

In table A4 we give the results from testing Granger causality and weak exogeneity in the long-term (36 months) data using the point values for the RHS variables. See table A2 for the variable notations and description of all the reported test statistics.

\begin{tabular}{|c|c|c|c|c|c|c|c|c|c|c|c|}
\hline Country & & anger Causa & & Weak Ex. & $\overline{\alpha \alpha}$ & Country & & anger Causa & & Weak Ex. & $\overline{\alpha \alpha}$ \\
\hline UK, ex post & $\Delta q$ & $\Delta\left(r^{*}-r\right)$ & $\Delta\left(d^{*}-d\right)$ & & & UK, ex ante & $\Delta q$ & $\Delta\left(r^{*}-r\right)$ & $\Delta\left(d^{*}-d\right)$ & & \\
\hline$\Delta q$ & na & na & na & na & na & $\Delta q$ & $17.38^{\# \# \#}$ & $2.33^{\#}$ & .19 & .03 & .001 \\
\hline$\Delta\left(r^{*}-r\right)$ & na & na & na & na & na & $\Delta\left(r^{*}-r\right)$ & 1.13 & $13.24^{\# \# \#}$ & .89 & $4.09^{\# \#}$ & $-.044^{\# \# \#}$ \\
\hline$\Delta\left(d^{*}-d\right)$ & na & na & na & na & na & $\Delta\left(d^{*}-d\right)$ & .66 & .02 & 1.19 & $3.69^{\#}$ & .002 \\
\hline Canada, ex post & & & & & & Canada, ex ante & & & & & \\
\hline$\Delta q$ & $5.01^{\# \# \#}$ & 1.62 & .53 & .08 & $-.004^{\#}$ & $\Delta q$ & $4.34^{\# \# \#}$ & 1.80 & .43 & .03 & .000 \\
\hline$\Delta\left(r^{*}-r\right)$ & 1.76 & 1.87 & .95 & $17.28^{\# \# \#}$ & $.72^{\# \# \#}$ & $\Delta\left(r^{*}-r\right)$ & .62 & $7.70^{\# \# \#}$ & .39 & .29 & -.001 \\
\hline$\Delta\left(d^{*}-d\right)$ & 1.58 & $2.51^{\#}$ & $3.47^{\# \#}$ & $5.67^{\# \#}$ & .027 & $\Delta\left(d^{*}-d\right)$ & .63 & $2.95^{\# \#}$ & $6.49^{\# \# \#}$ & $21.49^{\# \# \#}$ & $-.001^{\# \# \#}$ \\
\hline Japan, ex post & & & & & & Japan, ex ante & & & & & \\
\hline$\Delta q$ & $17.29^{\# \# \#}$ & .54 & $2.99^{\# \#}$ & .71 & $-.004^{\# \# \#}$ & $\Delta q$ & na & na & na & na & na \\
\hline$\Delta\left(r^{*}-r\right)$ & .81 & 2.18 & .77 & 2.10 & .38 & $\Delta\left(r^{*}-r\right)$ & na & na & na & na & na \\
\hline$\Delta\left(d^{*}-d\right)$ & 2.02 & .10 & $2.87^{\#}$ & $5.44^{\# \#}$ & .000 & $\Delta\left(d^{*}-d\right)$ & na & na & na & na & na \\
\hline Eurozone, ex post & & & & & & Eurozone, ex ante & & & & & \\
\hline$\Delta q$ & $19.38^{\# \# \#}$ & $6.97^{\# \# \#}$ & .99 & $6.39^{\# \# \#}$ & -.001 & $\Delta q$ & $10.31^{\# \# \#}$ & .03 & .73 & .81 & .003 \\
\hline$\Delta\left(r^{*}-r\right)$ & $2.58^{\#}$ & .75 & .65 & $55.00^{\# \# \#}$ & $.708^{\# \# \#}$ & $\Delta\left(r^{*}-r\right)$ & 1.24 & 1.26 & 2.99 & $11.44^{\# \# \#}$ & $-.001^{\# \# \#}$ \\
\hline$\Delta\left(d^{*}-d\right)$ & .24 & .85 & .69 & 1.03 & .001 & $\Delta\left(d^{*}-d\right)$ & $2.84^{\#}$ & 1.51 & $3.45^{\# \#}$ & $8.42^{\# \# \#}$ & -.001 \#\#\# \\
\hline
\end{tabular}


UK
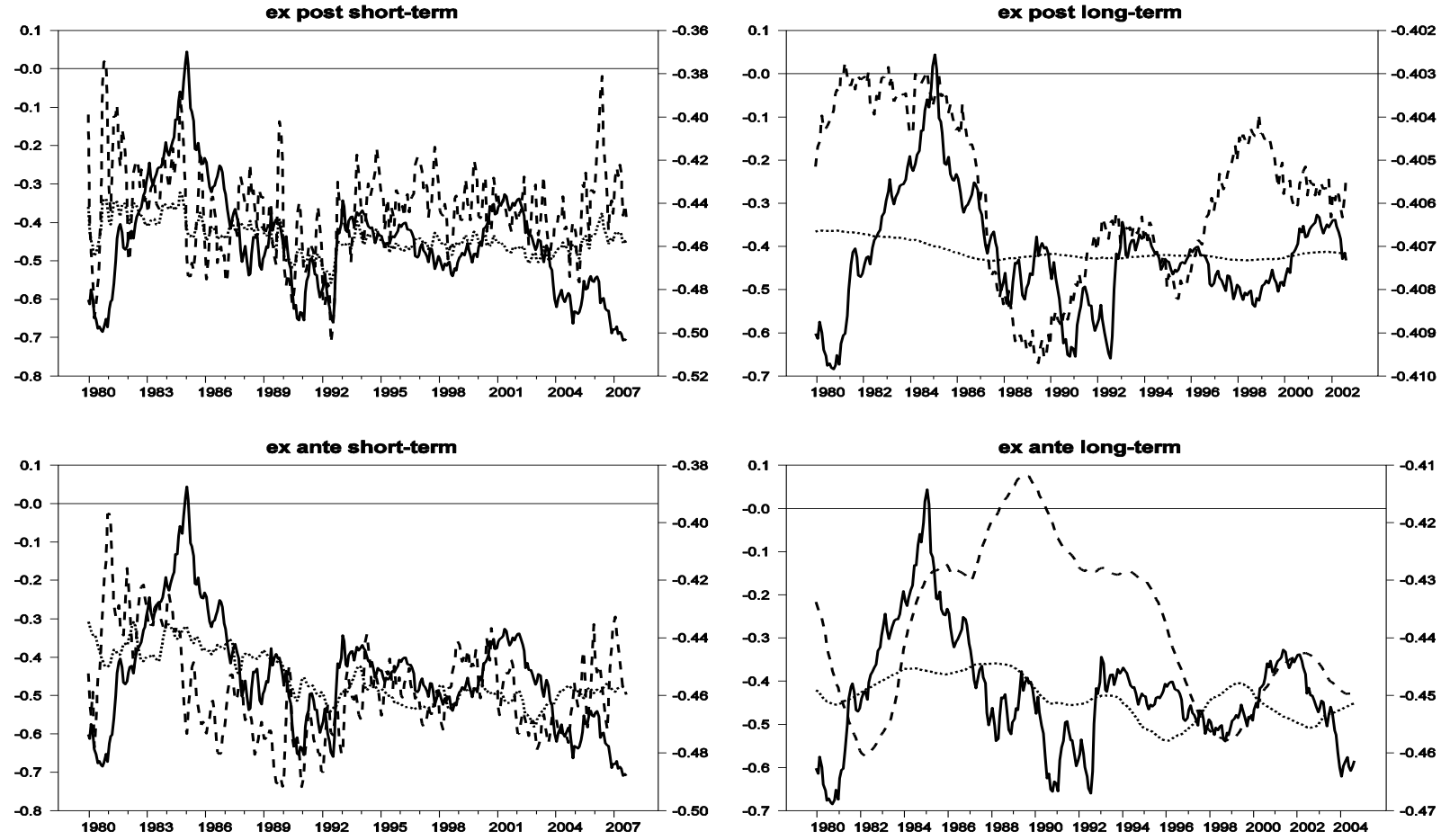

Canada
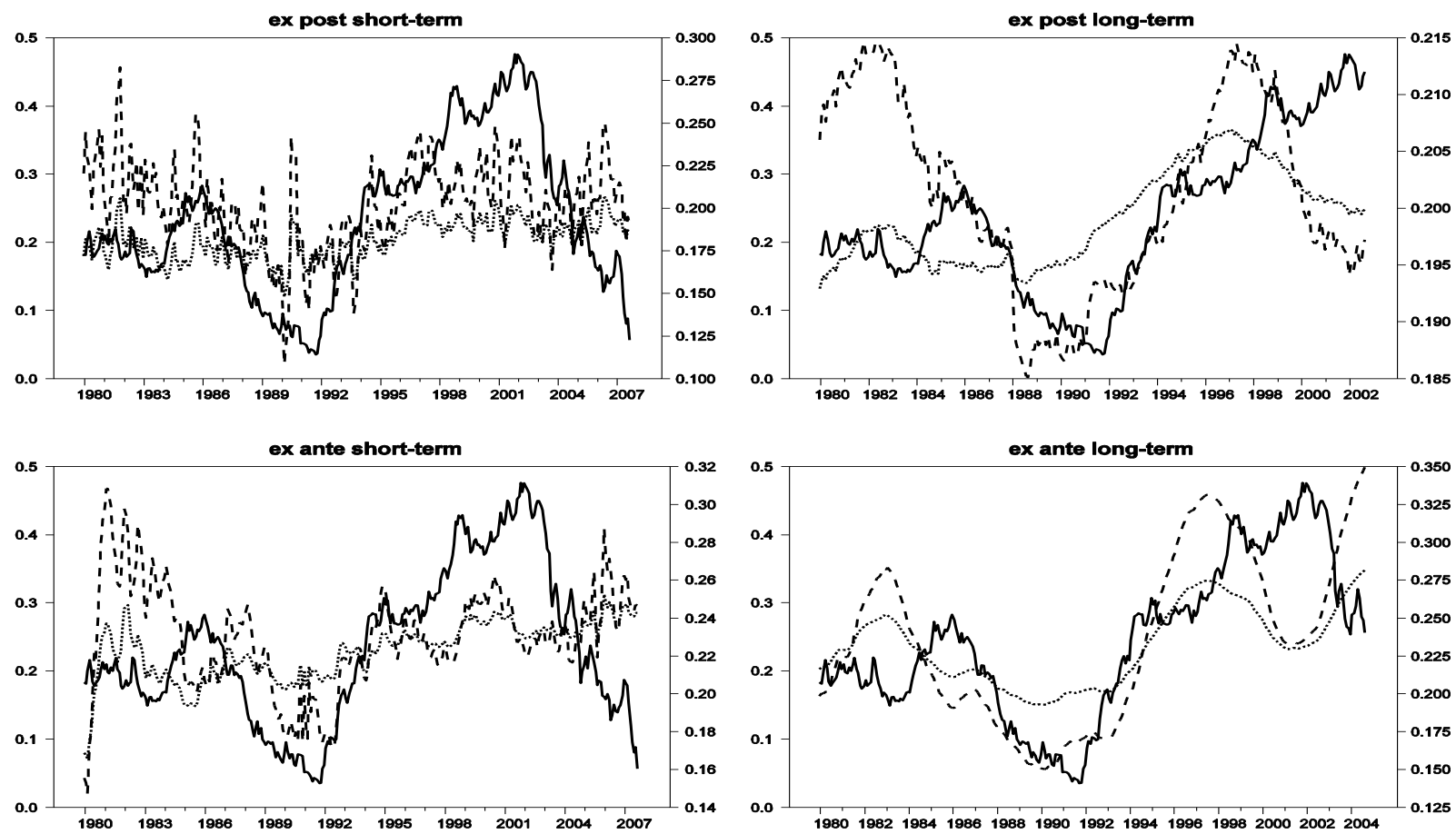

Figure 1. Comparison of the Real Exchange Rate (-) to the fitted values from the OLS regression of the traditional RERI (---) and Augmented Model (•••). 
Figure 1 continues

Japan
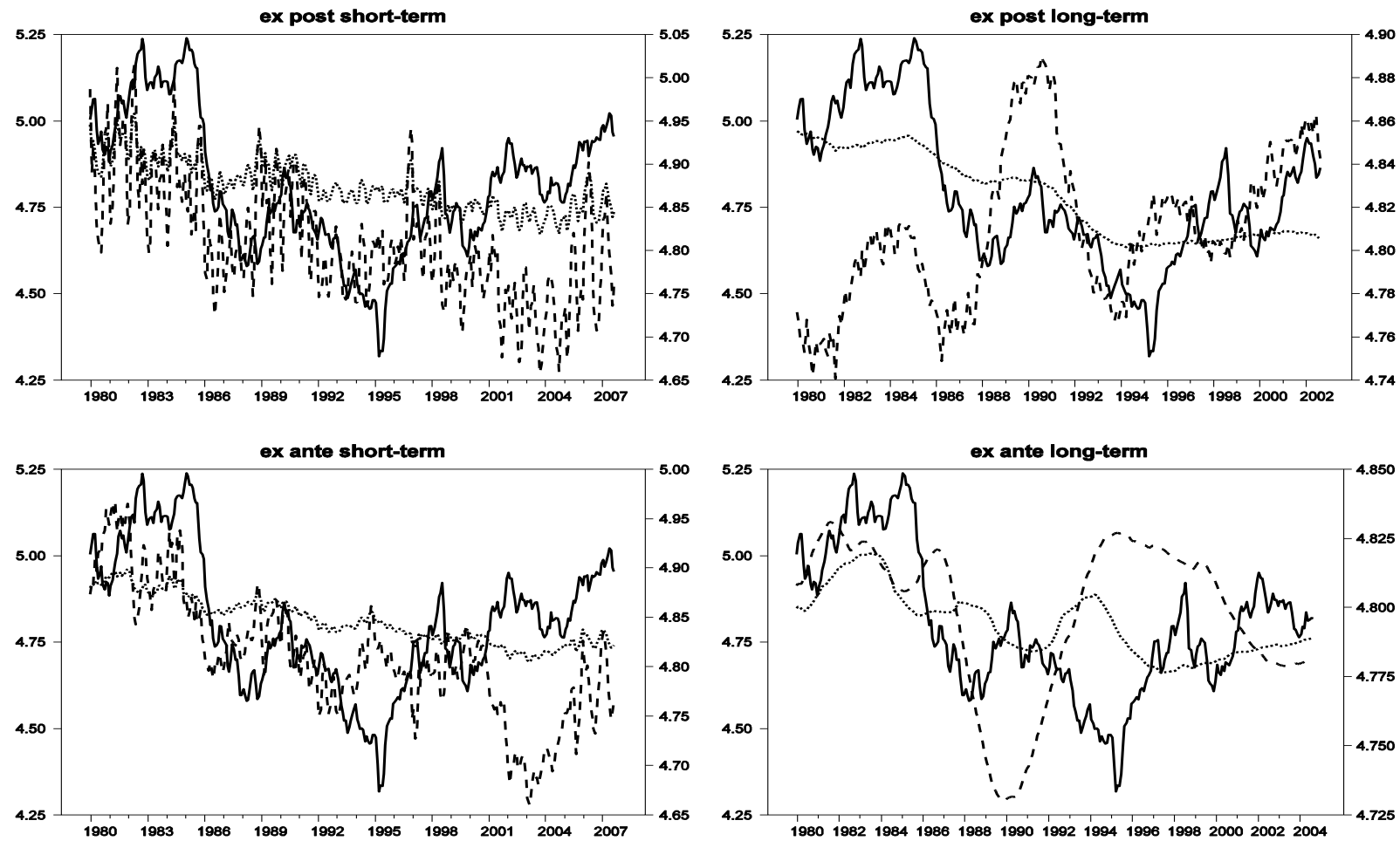

Eurozone
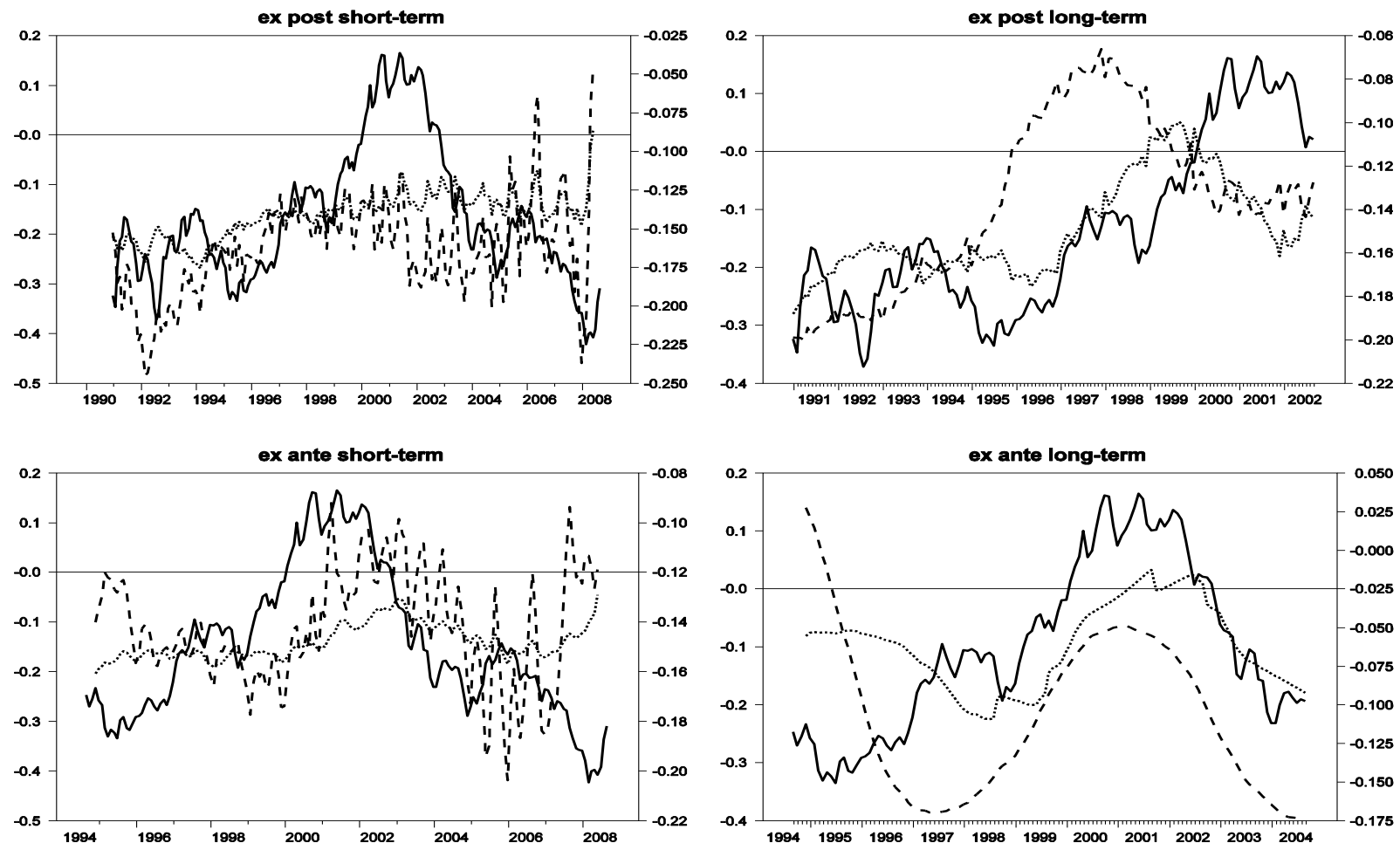